\title{
Role of Stress-Survival Pathways and Transcriptomic Alterations in Progression of Colorectal Cancer: A Health Disparities Perspective
}

\author{
Urbashi Basnet ${ }^{1}$, Abhijeet R. Patil ${ }^{2} \mathbb{D}$, Aditi Kulkarni ${ }^{1}$ and Sourav Roy ${ }^{1,3, *(\mathbb{D})}$ \\ 1 Department of Biological Sciences, University of Texas at El Paso, El Paso, TX 79968, USA; \\ ubasnet@utep.edu (U.B.); avkulkarni@utep.edu (A.K.) \\ 2 Computational Science Program, University of Texas at El Paso, El Paso, TX 79968, USA; \\ arpatil@miners.utep.edu \\ 3 The Border Biomedical Research Center, University of Texas at El Paso, El Paso, TX 79968, USA \\ * Correspondence: sroy1@utep.edu
}

Citation: Basnet, U.; Patil, A.R.; Kulkarni, A.; Roy, S. Role of Stress-Survival Pathways and Transcriptomic Alterations in Progression of Colorectal Cancer: A Health Disparities Perspective. Int. J. Environ. Res. Public Health 2021, 18, 5525. https://doi.org/10.3390/ ijerph18115525

Academic Editors: Elizabeth O. Ofili, Emma Fernandez-Repollet,

Richard J. Noel, Daniel F. Sarpong, Magda Shaheen, Paul B. Tchounwou, Kristen J. Wells and Richard Yanagihara

Received: 31 March 2021

Accepted: 19 May 2021

Published: 21 May 2021

Publisher's Note: MDPI stays neutral with regard to jurisdictional claims in published maps and institutional affiliations.

Copyright: (c) 2021 by the authors. Licensee MDPI, Basel, Switzerland This article is an open access article distributed under the terms and conditions of the Creative Commons Attribution (CC BY) license (https:// creativecommons.org/licenses/by/ $4.0 /)$.

\begin{abstract}
Every year, more than a million individuals are diagnosed with colorectal cancer (CRC) across the world. Certain lifestyle and genetic factors are known to drive the high incidence and mortality rates in some groups of individuals. The presence of enormous amounts of reactive oxygen species is implicated for the on-set and carcinogenesis, and oxidant scavengers are thought to be important in CRC therapy. In this review, we focus on the ethnicity-based CRC disparities in the U.S., the negative effects of oxidative stress and apoptosis, and gene regulation in CRC carcinogenesis. We also highlight the use of antioxidants for CRC treatment, along with screening for certain regulatory genetic elements and oxidative stress indicators as potential biomarkers to determine the CRC risk and progression.
\end{abstract}

Keywords: oxidative stress; antioxidants; apoptosis; gene regulation; microRNAs; biomarkers

\section{Introduction}

According to the World Health Organization, there were approximately 1.8 million new colorectal cancer (CRC) cases and around 861,000 deaths recorded in 2018 across the world [1]. In the U.S., CRC is ranked as the second deadliest cancer [2]. A decline in both the incidence and death rate has been observed in the U.S. over the past few years [2]. The current improvements are believed to be related to an increase in the CRC screening rate and lifestyle modifications with less exposure to risk factors [3]. Though there has been a significant decline in the CRC incidence rate among older adults, there is an ongoing opposite trend among younger adults. It is estimated that the incidence of colon and rectal cancer among the younger adults within the age group 20 to 34 years could rise by $90 \%$ and $124.2 \%$ respectively, in the U.S., by 2030 [4]. The increased incidence rate in the younger population can be related to hereditary colorectal cancer syndrome, age, stress, high-fat and low-fiber diet, inactive lifestyle, tobacco smoking, or metabolic diseases [5,6]. However, precise etiologies behind the CRC incidence spike are yet to be discovered [4]. Along with the younger population, certain ethnic and racial minorities are also known to be disparities in CRC incidence and mortality as compared to Non-Hispanic Whites [7,8]. The susceptibility of these minority groups to CRC may be attributed to their lack of knowledge, inadequate healthcare facilities, or hereditary factors [9].

The malignant transformation of normal colonic mucosal cells is a multi-step process and may take 5 to 10 years [10]. Chromosomal instability and mutation in several tumor suppressor genes may lead to non-cancerous adenomatous polyps becoming cancerous in a majority of colorectal cancer cases [11]. Continuous genetic and epigenetic alterations, like DNA methylation or histone modification, in the normal colonic epithelial cells may lead to the development of colonic adenoma or adenocarcinoma [12]. In some cases, epigenetic 
regulators like microRNAs (miRNAs) are also involved in colon carcinogenesis, where they either inhibit the expression of tumor suppressor genes or promote the expression of oncogenes $[13,14]$. Interestingly, miRNA binding site polymorphism in inflammatory genes has been known to modulate the risk of CRC progression in different populations [15]. Genome-wide association studies have verified up to 52 independent loci that could regulate CRC development [16,17]. Additionally, certain genes regulating different pathways have been identified to contribute to the progression of CRC $[18,19]$.

Besides genetic factors, extensive research is being conducted to determine the contribution of oxidative stress to the development of CRC [20]. The overaccumulation of reactive oxygen species (ROS) or reactive nitrogen species (RNS) in a cellular environment can damage the structure and function of the cells, leading to somatic mutation and neoplastic transformation [21]. Both ROS and RNS are highly reactive and are formed in vivo via oxidation-reduction reactions. These are essential in normal cells for signal transduction and phagocytosis [22]. However, ROS levels are usually higher in cancer cells compared to normal cells; and the imbalance in ROS production and the antioxidant defense mechanism typically results in irreversible cellular damage due to the oxidation of cellular macromolecules [23-25]. When present in enormous amounts though, they may initiate apoptosis or cell death leading to anticancer activity [26]. Altogether, it is evident that CRC carcinogenesis is a complex process, in which cross-talks between environmental and lifestyle factors lead to the regulation of multiple molecular pathways for its occurrence. These intricate interactions may also be the cause of resistance to drug or radiation-based therapies, implying a dire need for improved therapies to control one of the leading causes of cancer-based mortalities. In this review, we highlight the current health disparities in CRC and how gene regulation, oxidative stress pathways, and apoptosis relate to the progression of CRC. Further, we also discuss how these pathways and regulatory genes, including some miRNAs, could be used as biomarkers or therapeutic targets for CRC.

\section{CRC and Health Disparity}

According to the American Cancer Society, racial and ethnic minority groups in the U.S. have higher CRC-associated mortality in comparison to the overall population [7]. The colorectal cancer disparity is mostly based on socioeconomic status and race [8]. Though the incidence and mortality rate of CRC decreased annually by 3\% from 2001 to 2010 nationally [3], the decline in CRC cases is not equally applicable to the entire population. The decline in CRC mortality is significant among Non-Hispanic White (males and females) compared to all other races [27]. There is a high incidence and mortality rate among African Americans when compared to Non-Hispanic Whites and Asians [7]. CRC is ranked as the second most common cause of mortality in the Hispanic population among all cancers [28]. Hispanics contribute to more than $17 \%$ of the total US population [29], but fall far behind when it comes to healthcare, as compared to the Non-Hispanic White population. As a result, Hispanic populations are usually diagnosed with colorectal cancer at a later stage, which limits their survival rate [30]. Since the progression of precancerous polyps to laterstage CRC is a prolonged process, early detection or screening for CRC could prevent the severity of the disease [31]. However, there are multifactorial reasons for CRC screening disparity among different populations in the U.S. [32]. Though African American men have the highest mortality rate due to $C R C$, the screening rate is much lower among this population. In the Hispanic population as well, CRC screening is conducted at a much lower rate compared to the Non-Hispanic White population. A study conducted in the Hispanic population living in El Paso, Texas, concluded that there is a lack of awareness and presence of perceived barriers for CRC screening in this ethnic group [33]. Other factors such as poor access to healthcare facilities, genetic predisposition to CRC, and the presence of higher CRC risk factors in the minority groups may also contribute to the higher statistics [9].

Globally, CRC is the third most diagnosed cancer. There is a higher risk of CRC in developed countries, but the incidence of CRC varies from region to region [34]. GLOBCAN 
studies have shown that there is a CRC gender disparity with a 50\% higher cumulative risk in men as compared to women. The lesser incidence of CRC in females has been attributed to the female sex hormone, estrogen, which has adverse effects on the progression of CRC [35]. Though men are more susceptible to CRC, right-sided colon cancer (RCC) is more prevalent among females due to their ability to synthesize the amino acid asparagine abundantly and higher amino acid uptake [36]. Environmental factors, genetic and epigenetic changes, and distinguishing molecular features of males and females could also be the reasons for sex disparity in CRC [37]. BRAF mutation, one of the important factors in CRC is more commonly seen in females than males [38]. Besides demographic and racial backgrounds, $12 \%$ of colorectal cancer cases have also been related to consumption of the western diet [39]. Obesity among African Americans and Hispanics compared to Whites is considered as a predisposing risk factor for early onset of CRC [40]. A diet comprising highly processed food with high levels of fat, sodium, sugar, and low essential minerals and vitamins, is considered as a factor for the increasing rate of CRC cases [41]. Low CRC screening rates in Hispanic females who regularly consume alcohol [42], and the ability to metabolize alcohol due to genetic polymorphisms in enzymes involved in alcohol metabolism in Asians [43-45], have been correlated to a higher CRC incidence rate in these populations. Ethanol and/or its metabolites produced upon alcohol consumption are known to induce colon carcinogenesis by affecting lipid metabolism, epithelial to mesenchymal transition (EMT), angiogenesis, or adverse immune responses [46]. Expression of miRNAs such as $m i R-34 a, m i R-21$, and $m i R-135$ is also seen to be altered by ethanol, affecting several oncogenic cell-signaling pathways linked to colorectal carcinogenesis [46].

Several methods have been employed to increase the screening rates in high-risk ethnic groups, including prioritizing physician recommendations, improved healthcare coverage, and patient navigators, but they have been met with heterogenous success [47,48]. Despite these measures, colonoscopy rates have increased only among Non-Hispanic Whites, and decreased among minority groups $[49,50]$. Previous studies have suggested that there is a higher rate of screening if the minority groups were offered the fecal occult blood (FOB) tests compared to colonoscopy [51]. However, there is a geographic variation observed in the availability and acceptance of the FOB testing method. Further studies are required to decipher the receptiveness of the FOB test in minority groups across the U.S., which would provide a better comparison with colonoscopy and aid in improving their participation in routine CRC screenings.

\section{Genetic Alterations in CRC}

CRC is a multistep process that is described by a shift in the gene expression profile when the cell starts to evolve from the early to the late stage of CRC [52]. In this section, we focus on some of the genes that have been identified to be related to tumorigenesis and metastasis of CRC (Table 1). The cell cycle and p53 signaling pathways are seen to be among the top enriched pathways in CRC transcriptomes [19]. The genes involved in the cell cycle promote the endothelial cell proliferation that contributes to the tumor progression and metastasis of CRC [53]. One of the key regulators, cyclin-dependent kinase 1 (CDK1), is seen to be highly enriched in CRC patients [54]. Another cell cycle gene, Cyclin A2 (CCNA2) shows higher expression in CRC than in normal tissues, and knockdown of CCNA2 is known to suppress the CRC cell growth significantly by impairing the cell cycle progression and promoting cell apoptosis [55]. Alterations in the p53 signaling pathway due to mutations in the TP53 gene are also associated with the loss of the transactivation feature in advanced CRC cases, which leads to poor survival [56]. However, activation of p53 may also be related to cellular stress, which could target downstream genes that can influence apoptosis, cell cycle arrest, and angiogenesis through mRNA:miRNA interactions [57]. The ribonucleotide reductase regulatory subunit $\mathrm{m} 2$ (RRM2) gene, which is a part of the cell cycle and p53 signaling pathway, is also known to be overexpressed in CRC [18], and has been correlated with the poorly differentiated type, invasion depth, and tumor node metastasis stages in CRC [18]. Among the other cell cycle and p53 sig- 
naling pathway genes are DNA topoisomerase 2-alpha (TOP2A) [58], cell division cycle 6 (CDC6) [59,60], nucleolar and spindle associated protein 1 (NUSAP1) [61], centrosomal protein 55 (CEP55) [62], budding uninhibited by benzimidazoles 1 (BUB1) [63], and the mitotic arrest deficient 2 like 1 (MAD2L1) [63], which are known to be differentially expressed in CRC, and are related to the aggressive tumor phenotypes and advanced tumor stages.

Table 1. Differentially expressed genes during CRC carcinogenesis.

\begin{tabular}{|c|c|c|c|c|}
\hline Gene & Function(s) & Role in CRC Progression & Pathway & UR/DR \\
\hline AURKA & $\begin{array}{l}\text { Regulates mitotic spindle } \\
\text { formation [64]. }\end{array}$ & $\begin{array}{l}\text { Contributes to malignant } \\
\text { transformation of colorectal adenomas } \\
\text { to carcinoma }[65,66] \text {. }\end{array}$ & Cell cycle & UR \\
\hline BUB1 & $\begin{array}{l}\text { Assembles spindle checkpoint } \\
\text { proteins at kinetochore, and is } \\
\text { required for chromosome } \\
\text { alignment [67]. }\end{array}$ & $\begin{array}{l}\text { Mutations in the BUB1 gene cause } \\
\text { chromosome missegregation during } \\
\text { CRC progression [68]. However, the } \\
\text { role of BUB1 in CRC development } \\
\text { remains poorly understood. }\end{array}$ & Cell cycle & UR \\
\hline CCNA2 & $\begin{array}{l}\text { Activates CDK1 and CDK2 to } \\
\text { promote somatic cell division } \\
{[69,70] \text {. }}\end{array}$ & $\begin{array}{l}\text { Promotes G1/S and G2/M phase } \\
\text { transitions in CRC cells with reduced } \\
\text { apoptotic cells [55]. }\end{array}$ & Cell cycle & DR \\
\hline CD48 & $\begin{array}{l}\text { Activate T cells, } \\
\text { antigen-presenting cells and } \\
\text { granulocytes [71]. }\end{array}$ & $\begin{array}{l}\text { Target of NF-kB signaling during CRC } \\
\text { invasion [72]. }\end{array}$ & Innate immunity & DR \\
\hline CDC6 & $\begin{array}{l}\text { Required for formation of the } \\
\text { pre-replicative complex. } \\
\text { Regulates G1, S, and mitosis } \\
\text { phases in the eukaryotic cell } \\
\text { cycle [73]. }\end{array}$ & $\begin{array}{l}\text { Human antigen } \mathrm{R}(\mathrm{HuR}) \text { regulates } \\
\text { CDC6 activity to promotes cell } \\
\text { proliferation with increased DNA } \\
\text { synthesis, epithelial-mesenchymal } \\
\text { transition (EMT), migration, invasion } \\
\text { in CRC, and confers resistance to } \\
\text { oxaliplatin [60]. }\end{array}$ & Cell cycle & UR \\
\hline CDK1 & $\begin{array}{l}\text { Controls cell cycle by regulating } \\
\text { mitotic onset [74]. }\end{array}$ & $\begin{array}{l}\text { Phosphorylates JAK1 and triggers } \\
\text { JAK/STAT3 signaling pathway to } \\
\text { promote CRC metastasis [75]. }\end{array}$ & Cell cycle & UR \\
\hline CEP55 & $\begin{array}{l}\text { Centromere protein that is } \\
\text { required for mitotic exit and } \\
\text { cytokinesis [76]. }\end{array}$ & $\begin{array}{l}\text { Activate } \mathrm{p} 53 / \mathrm{p} 21 \text { axis to promote } \\
\text { CRC proliferation and metastasis, and } \\
\text { mutation in CEP55 gene have been } \\
\text { related to overall CRC patient survival } \\
\text { [62]. }\end{array}$ & Cell cycle & UR \\
\hline CHEK1 & $\begin{array}{l}\text { Regulates checkpoint-mediated } \\
\text { cell cycle arrest, and DNA repair } \\
\text { in response to any DNA damage } \\
\text { [77]. }\end{array}$ & $\begin{array}{l}\text { Reduced expression of } C H E K 1 \text { has } \\
\text { been speculated to be an important } \\
\text { inactivating mechanism for impaired } \\
\text { DNA polymerase function and the } \\
\text { development of colorectal neoplasm } \\
{[78,79] \text {. }}\end{array}$ & Cell cycle & DR \\
\hline CLCA4 & $\begin{array}{l}\text { Calcium activated chlorine } \\
\text { transport [80]. }\end{array}$ & $\begin{array}{l}\text { Inhibits cell invasion and migration } \\
\text { through suppression of EMT via the } \\
\text { PI3K/AKT pathway in CRC [80]. }\end{array}$ & Ion channel transport & DR \\
\hline CXCL1 & $\begin{array}{l}\text { Recruits neutrophils to activate } \\
\text { the host immune system for } \\
\text { microbial killing [81,82]. }\end{array}$ & $\begin{array}{l}\text { Proinflammatory mediators such as } \\
\text { prostaglandin E2 are thought to } \\
\text { induce CXCL1 targeted angiogenesis } \\
\text { in CRC [83]. }\end{array}$ & $\begin{array}{l}\text { Phagocytosis and } \\
\text { inflammation }\end{array}$ & UR \\
\hline
\end{tabular}


Table 1. Cont.

\begin{tabular}{|c|c|c|c|c|}
\hline Gene & Function(s) & Role in CRC Progression & Pathway & UR/DR \\
\hline CXCL3 & $\begin{array}{l}\text { Chemotactic activity for } \\
\text { neutrophils [84]. }\end{array}$ & $\begin{array}{l}\text { Gene set enrichment analysis in CRC } \\
\text { samples has revelated that elevated } \\
\text { CXCL3 levels could be associated with } \\
\text { impaired DNA repair, cell cycle } \\
\text { process, cell apoptosis process, and } \\
\text { the p53 regulation pathway; however, } \\
\text { further studies are required to } \\
\text { decipher the prospective molecular } \\
\text { mechanism [85]. }\end{array}$ & $\begin{array}{l}\text { Phagocytosis and } \\
\text { inflammation }\end{array}$ & UR \\
\hline CXCL8 & $\begin{array}{l}\text { Acts as a chemotactic factor that } \\
\text { attracts neutrophils, basophils, } \\
\text { and T-cells, but not monocytes } \\
{[86,87] \text {. }}\end{array}$ & $\begin{array}{l}\text { Induces EMT of CRC cells to aid in } \\
\text { evasion host immunosurveillance and } \\
\text { enhance anoikis resistance to promote } \\
\text { distant organ colonization [88]. }\end{array}$ & $\begin{array}{l}\text { Phagocytosis and } \\
\text { inflammation }\end{array}$ & UR \\
\hline$E V I 2 B$ & $\begin{array}{l}\text { Control granulocyte } \\
\text { differentiation and functionality } \\
\text { [89]. }\end{array}$ & $\begin{array}{l}\text { CRC proliferation, migration, and } \\
\text { invasion have been correlated with } \\
\text { reduced expression of } E V I 2 B \text { [90]. } \\
\text { Functional studies to determine } \\
\text { downstream molecular target(s) need } \\
\text { attention. }\end{array}$ & Cell cycle & DR \\
\hline GPX1 & $\begin{array}{l}\text { Catalyzes the reduction of } \\
\text { hydrogen peroxide to water and } \\
\text { oxygen [91] }\end{array}$ & $\begin{array}{l}\text { Though the levels of GPX1 are seen to } \\
\text { increase in CRC tissues [92], possible } \\
\text { modes of action of these enzymes in } \\
\text { CRC progression need further } \\
\text { investigation. }\end{array}$ & Oxidative stress & UR \\
\hline HCLS1 & $\begin{array}{l}\text { Plays an important role in } \\
\text { lymphocyte trafficking, } \\
\text { neutrophil chemotaxis, and } \\
\text { growth arrest [93-95] }\end{array}$ & $\begin{array}{l}\text { Target of } m i R-1296-5 p \text { mediated } \\
\text { endonucleolytic cleavage in CRC } \\
\text { carcinogenesis [96]. }\end{array}$ & $\begin{array}{l}\text { Cell cycle and } \\
\text { immunity }\end{array}$ & DR \\
\hline$M A D 2 L 1$ & $\begin{array}{l}\text { Chromosome alignment at the } \\
\text { metaphase plate [97]. }\end{array}$ & $\begin{array}{l}\text { The expression of MAD2L1 is seen to } \\
\text { increase gradually with the stages I-IV } \\
\text { of CRC [98], suggesting it could be } \\
\text { important for tumor progression, but } \\
\text { its clinical function in CRC is still } \\
\text { unknown. }\end{array}$ & Cell cycle & UR \\
\hline$M E L K$ & $\begin{array}{l}\text { Interacts and phosphorylates } \\
\text { with BCL-G, CDC25B, MAPK, } \\
\text { NIPP1, p53 to regulate the cell } \\
\text { cycle, self-renewal of stem cells, } \\
\text { and apoptosis [99]. }\end{array}$ & $\begin{array}{l}\text { Phosphorylates AKT through } \\
\text { FAK/Src pathway to increase } \\
\text { proliferation, migration, and invasion } \\
\text { of CRC cells [100]. }\end{array}$ & Cell cycle & UR \\
\hline NUSAP1 & $\begin{array}{l}\text { Microtubule organization and } \\
\text { chromosome segregation during } \\
\text { cell division [101]. }\end{array}$ & $\begin{array}{l}\text { Promotes cell proliferation, migration, } \\
\text { invasion, and EMT in CRC via DNA } \\
\text { methyltransferase } 1 \text { (DMT1) } \\
\text { expression [61]. }\end{array}$ & Cell cycle & UR \\
\hline PLK1 & $\begin{array}{l}\text { Performs several important } \\
\text { functions during mitosis along } \\
\text { with mitotic exit and cytokinesis } \\
\text { [102]. }\end{array}$ & $\begin{array}{l}\text { Acts as an indispensable protein in } \\
\text { cellular mitosis and proliferation, and } \\
\text { is crucial for migration and invasion } \\
\text { in CRC [103]. }\end{array}$ & Cell cycle & UR \\
\hline
\end{tabular}


Table 1. Cont.

\begin{tabular}{|c|c|c|c|c|}
\hline Gene & Function(s) & Role in CRC Progression & Pathway & UR/DR \\
\hline PRDX1 & $\begin{array}{l}\text { Protects the cells against } \\
\text { oxidative stress by reducing } \\
\text { peroxides to oxygen and water } \\
\text { [104]. }\end{array}$ & $\begin{array}{l}\text { Upregulated PRDX1, increases the } \\
\text { production of matrix proteins } \\
\text { (MMP2/MMP9) or growth factors } \\
\text { (VEGFA) [105], reduces the } \\
\text { production of proinflammatory } \\
\text { cytokines and chemokines (IL-8 and } \\
\text { CXCL1) [106], or interacts with PARP } \\
\text { tankyrase to promote tumor } \\
\text { development via APC [107]. }\end{array}$ & Oxidative stress & UR \\
\hline RRM2 & $\begin{array}{l}\text { Synthesizes deoxynucleotides } \\
\text { from ribonucleotides for DNA } \\
\text { polymerization and repair, and } \\
\text { supplies dNTPs for } \\
\text { mitochondrial DNA replication } \\
\text { and repair via p53 [108-110]. }\end{array}$ & $\begin{array}{l}\text { Regulates infiltration and metastasis } \\
\text { by increasing hyperplasia and cell } \\
\text { invasion [18]. }\end{array}$ & $\begin{array}{l}\text { Cell cycle, p53 } \\
\text { signaling }\end{array}$ & UR \\
\hline SOD1 & $\begin{array}{l}\text { Converts superoxide radicals } \\
\text { into hydrogen peroxide and } \\
\text { oxygen [11]]. }\end{array}$ & $\begin{array}{l}\text { SOD production levels are seen to } \\
\text { increase proportionally with CRC } \\
\text { severity [112]; though, further studies } \\
\text { are required to determine the } \\
\text { downstream functional pathway. }\end{array}$ & Oxidative stress & UR \\
\hline TOP2A & $\begin{array}{l}\text { Regulates chromosome } \\
\text { condensation, chromatid } \\
\text { separation, transient breaking, } \\
\text { and rejoining of DNA strands } \\
\text { during transcription and DNA } \\
\text { replication by altering the DNA } \\
\text { topology [113]. }\end{array}$ & $\begin{array}{l}\text { High copy numbers have been } \\
\text { associated with mismatch repair } \\
\text { (MMR) competent CRC patients [114], } \\
\text { but have also been associated with } \\
\text { aggressive and advanced CRC } \\
\text { phenotypes due to their ability to } \\
\text { inhibit apoptosis and induce drug } \\
\text { resistance [58]. }\end{array}$ & Cell cycle & UR \\
\hline TP53 & $\begin{array}{l}\text { Tumor suppressor protein that } \\
\text { acts as a transcription factor to } \\
\text { regulate cell division and DNA } \\
\text { repair [115]. }\end{array}$ & $\begin{array}{l}\text { Mutations in the TP53 gene, impair } \\
\text { the transactivational ability of p53 to } \\
\text { initiate downstream gene expression } \\
\text { to regulate cell cycle arrest, apoptosis, } \\
\text { and angiogenesis }[56,57] \text {. }\end{array}$ & p53 signaling & DR \\
\hline
\end{tabular}

DR-Downregulated; UR-Upregulated.

The risk of CRC carcinogenesis has also been associated with genes modulating the oxidative stress pathway. The genes encoding for peroxiredoxin 1 (PRDX1), glutathione peroxidase 1 (GPX1), and superoxide dismutase $(S O D)$ have been seen to be highly upregulated in CRC samples [92,105-107,116]. The proteins encoded by these genes are known to be crucial for oxidative balance in cells; however, their role or mechanism of interaction in CRC metastasis and angiogenesis remains understudied [105,116]. For decades, the use of manganese-SOD or zinc/copper-SOD is under evaluation as treatment(s) for CRC. However, there has been limited evidence about their prognostic value from either of the clinicopathological stages of CRC [92]. Recent studies suggest, PRDX1 reduces the production of pro-inflammatory cytokines IL-8 and CXCL1 [106], or interacts with poly(ADP-ribose) polymerase (PARP) tankyrase to promote tumor development via the adenomatous polyposis coli $(A P C)$ gene [107]. However, further studies to confirm PRDX1 as an inflammation marker in CRC development or as a therapeutic target against inflammation-associated CRC need to be conducted.

Apart from the genes associated with stress survival pathways, genes encoding for different kinases have also been seen to be differentially expressed in various CRC cases. The top candidates include serine/threonine-protein kinase (PLK1) [19,103], aurora kinase A (AURKA) [63], checkpoint kinase 1 (CHEK1) [78], and maternal embryonic leucine zipper kinase $(M E L K)$ [100]. These genes are seen to control the proliferation, migration, invasion 
of CRC cells, prognosis, or metastasis of CRC. Furthermore, genes encoding for cytokines belonging to the CXC family are crucial in regulating inflammation and angiogenesis in CRC [117]. Studies have identified CXCL1, CXCL3, and CXCL8 as the hub genes in the development of CRC [118]. Moreover, peptide tyrosine-tyrosine (PYY), calcium-activated chloride channel 4 (CLCA4), hematopoietic cell-specific lyn substrate 1 (HCLS1), ecotropic viral integration site $2 \mathrm{~B}(E V I 2 B)$, and cluster of differentiation $48(C D 48)$ are also some of the genes differentially expressed in CRC tissues [90,118]. Apart from differential gene expression patterns, a few genetic mutations have also been correlated with CRC incidence in populations of different ethnicities. Mutations in two genes, ephrin type A receptor 6 (EPHA6) and folliculin (FLCN), have been identified as CRC drivers in the African American population [119].

In the current era with advances in high-throughput genomic technologies, extracting information about specific gene expression profiles has become highly attainable. However, not many studies have been conducted to use this information to screen for potential therapeutic targets or biomarkers. Studying the biological significance of the expression of these genes in CRC progression and in promoting tumor aggressiveness or studying their influence on the tumor microenvironment would help design robust diagnostic tools or identify therapeutic targets for CRC in the future. For example, as CDK1 is known to be enriched in many cancer types, including breast cancer [120], pancreatic ductal adenocarcinoma [121], oral squamous cell carcinoma [122], and hepatocellular carcinoma [123], consideration of CDK1 as a potential biomarker may be advisable. Though oncogenic long non-coding RNA MALAT1 is considered as a poor prognostic indicator [124], the expression of MALAT1 is seen to be significantly higher in African Americans compared to CRC tissues of Caucasians, making it a marker for disparate CRC incidence and severity in African American population [125]. Microsatellite instability (MSI) has been used as a biomarker for detecting defective DNA MMR in CRCs [126-128]. It is typically assessed by analyzing at least five microsatellite markers: three dinucleotides (D2S123, D5S346, D17S250) and two mononucleotides (BAT25 and BAT26) repeats, as suggested by the National Cancer Institute's Bethesda panel [129]. Due to lower sensitivity rates, new quasi-monomorphic mononucleotide markers, known as the pentaplex panel have been applied [130]. Studies have shown differences in the MSI frequencies in African Americans and Puerto Rican Hispanics as compared to Caucasians [131,132]. However, no significant difference has been reported in a recent study comparing the frequency of MSI in different ethnic groups [133]; implying the need for evaluating the methodologies and biological sources used in other studies for further use of MSI as genetic markers. Investigating the role of oxidative stress-inducible genes as biomarkers or therapeutic targets would also provide insights into controlling CRC metastasis. From a therapeutic perspective, HCLS1, $E V 12 B$, and $C D 48$ genes are seen to be negatively associated with the prognosis of CRC patients [90]. Exploring the effects of overexpression of HCLS1, EV12B, and CD48 genes in reducing migration, proliferation, and invasion of $C R C$ cells and eventually suppressing CRC tumor growth could provide us with promising CRC therapies [90]. Further, deciphering ways to overcome TOP2A [58] or CXCL8 [134] mediated chemotherapeutic resistance is also of acute importance.

\section{Role of microRNAs in CRC Carcinogenesis}

Information-carrying biomolecules such as miRNAs, extracellular vesicles (or exosomes), circulating tumor cells, and cell-free DNA are known to regulate CRC metastasis through epithelial-mesenchymal transition, angiogenesis, immunosuppression, and chemoresistance [135-142]. Because of their importance in CRC carcinogenesis, these are considered potential biomarkers for disease progression and response to cancer therapies [135-142]. Though all of these have an excellent basis for use as genetic markers, due to their atypical expression patterns detected during CRC carcinogenesis, we focus on the roles of miRNAs in CRC progression and response to therapy in this section [135,136]. These are a family of small non-coding single-stranded regulatory RNAs comprising of 
19 to 25 nucleotides. They regulate gene expression by either mRNA degradation or by suppressing translation [143,144]. Though their role in tumor regulation has been known for more than 20 years [145], they have only recently been considered as a tool for CRC screening due to their aberrant expression during colorectal carcinogenesis $[135,136]$. Many microarray studies have shown that the miRNA profiles from healthy controls, patients with colorectal adenoma, and CRC are significantly different $[146,147]$. Some of the miRNAs (Table 2), miR-21, miR-92a, miR-135b, miR-18a, miR-18b, miR-31, miR-212, miR-431, and $m i R-503$, have been identified to be upregulated in different stages of CRC contributing to the transformation of normal mucosa to CRC [147-149]. On the contrary, miR-14, miR-451, $m i R-638, m i R-133 a, m i R-375, m i R-378, m i R-422$, and members of the miRNA-320 family are seen to be significantly downregulated in colorectal adenoma and CRC tissues $[147,149,150]$. These miRNAs are thought to target important cell cycle genes such as CDK6 [150], RAS p21 protein activator 1 (RASA1) [151], or KRAS gene [152] to promote cell proliferation, migration, and invasion in CRC. Approximately $230 \mathrm{miRNAs}$ are differentially expressed in colorectal adenocarcinoma samples collected from patients that had a pre-existing adenoma [153]. When compared with survival rate, nine key miRNAs, miR-125a, miR-125b, miR-328, miR-129, miR-217, miR-375, miR-486, miR-194, and miR-144, have been seen to be differentially expressed and had a direct correlation with survival rates in different colorectal adenocarcinoma cases [154]. In a small-scale study among the thirty African Americans and thirty-one Caucasian CRC subjects, five miRNAs (miR-182, miR-152, miR-204, miR-222, and miR-202) were found to be correlated to racial tumorigenesis [155]. Among these five miRNAs, miR-182 was observed to be highly upregulated in CRC tumors of African Americans compared to Caucasians; contributing significantly to the roles of miRNA in CRC racial disparity [155]. While the observations from this study regarding increased miR-182 expression in African Americans need further confirmation in larger sample sets along with better annotation of racial metadata in existing collections, it does provide evidence for racial differentiation in miRNA expression.

Table 2. Important miRNAs in CRC carcinogenesis.

\begin{tabular}{|c|c|c|c|}
\hline miRNA & Role(s) in CRC Progression & Target(s) & UR/DR \\
\hline$m i R-18 a$ & $\begin{array}{l}\text { It is the most conserved and multifunctional miRNAs and is often } \\
\text { overexpressed in tumors [156]. miR-18a has a dual functional role } \\
\text { in either promoting or inhibiting tumorigenesis in many human } \\
\text { cancers including CRC [156]. }\end{array}$ & $\begin{array}{l}\text { IRF2, PTEN } \\
\text { SOX6, WNK2 } \\
\text { STK4, PIAS3 } \\
\quad \text { CDC42 }\end{array}$ & UR \\
\hline$m i R-21$ & $\begin{array}{l}\text { Located within the intronic region of the TMEM49 gene. It plays a } \\
\text { crucial role in many biological functions and has been } \\
\text { upregulated in many diseases including cancer, cardiovascular } \\
\text { diseases, and inflammation [157]. miR-21 also plays important } \\
\text { roles in carcinoma-associated fibroblast formation, tumor } \\
\text { formation, and metastasis [158]. }\end{array}$ & $\begin{array}{l}\text { SMAD7 } \\
\text { PDCD4 } \\
\text { TPM1 } \\
\text { CDC25a } \\
\text { TIMP3 }\end{array}$ & UR \\
\hline $\operatorname{miR}-31$ & $\begin{array}{l}m i R-31 \text { has been shown to increase cell growth in CRC cells and } \\
\text { also stimulates oncogenesis by repressing RASA1 [151]. }\end{array}$ & $R A S A 1$ & UR \\
\hline$m i R-92 a$ & $\begin{array}{c}\text { Also known as oncomiR, it enhances cell proliferation, induces } \\
\text { tumor angiogenesis, suppresses apoptosis of cancer cells, and } \\
\text { promotes tumor progression in various cancers including CRC } \\
\text { [15]. Upregulated expression of miR-92a in plasma or stool has } \\
\text { shown to be effective in predicting CRC [159]. }\end{array}$ & $\begin{array}{l}\text { PTEN } \\
\text { SMAD2 } \\
\text { SMAD4 } \\
\text { TGFBR2 }\end{array}$ & UR \\
\hline$m i R-125 a / b$ & $\begin{array}{c}\text { miR-125 has shown to be involved in multiple cancers. It is } \\
\text { downregulated and inhibits cell proliferation, migration, and } \\
\text { invasion in CRC [160]. }\end{array}$ & $\begin{array}{l}\text { P53, PUMA } \\
\text { BAK }\end{array}$ & DR \\
\hline$m i R-126$ & $\begin{array}{l}\text { It contributes to cell proliferation, invasion, and progression of } \\
\text { angiogenesis. In highly metastatic CRC cell lines, the expression } \\
\text { of miR-126 is known to be significantly reduced }[15,161,162] \text {. }\end{array}$ & $\begin{array}{l}\text { P13K, CXCR4, VEGFA, } \\
\text { IRS1 }\end{array}$ & $\mathrm{DR}$ \\
\hline
\end{tabular}


Table 2. Cont.

\begin{tabular}{|c|c|c|c|}
\hline miRNA & Role(s) in CRC Progression & Target(s) & UR/DR \\
\hline$m i R-135 b$ & $\begin{array}{l}\text { It is common in sporadic and inflammatory bowel } \\
\text { disease-associated human colorectal carcinomas, and is correlated } \\
\text { with tumor stage [163]. miR-135b has a role in the early stages of } \\
\text { CRC [136]. }\end{array}$ & $A P C$ & UR \\
\hline$m i R-143$ & $\begin{array}{l}m i R-143 \text { regulates cell growth and proliferation [164]. It is a tumor } \\
\text { suppressor miRNA. It suppresses cell growth and proliferation by } \\
\text { repressing the translation of KRAS and DNMT3A [136]. }\end{array}$ & $\begin{array}{l}\text { DNMT3A } \\
\text { KRAS } \\
\text { CD44 }\end{array}$ & DR \\
\hline$m i R-155$ & $\begin{array}{l}\text { It is overexpressed in CRC and lung cancer. Mediates cell } \\
\text { proliferation, invasion, and angiogenesis [165]. It is also linked } \\
\text { with drug resistance, poor prognosis, and genome instability in } \\
\text { CRC patients [166]. miR-155 suppresses the expression of PTPRJ, } \\
\text { affecting cell proliferation and migration in CRC }[15,167] .\end{array}$ & $\begin{array}{l}\text { PTPRJ } \\
\text { TP53INP1 } \\
\text { MSH2, MSH6 } \\
\text { FOXO3 }\end{array}$ & UR \\
\hline$m i R-194$ & $\begin{array}{c}\text { It is closely associated with the overall survival of CRC patients, } \\
\text { tumor size, and tumor node metastasis (TNM) [15]. It suppresses } \\
\text { tumor growth by regulating the MAP4K4/c- Jun/MDM2 } \\
\text { signaling pathway [168]. }\end{array}$ & $M A P 4 K 4, A K T 2$ & DR \\
\hline$m i R-499$ & $\begin{array}{c}\text { miR-499 promotes cell migration and invasion in CRC cell lines } \\
\text { by targeting FOXO4 and PDCD4 [169]. }\end{array}$ & $\begin{array}{l}\text { FOXO4 } \\
\text { PDCD4 }\end{array}$ & UR \\
\hline
\end{tabular}

DR-Downregulated; UR-Upregulated.

As many studies are identifying the roles of miRNAs in the occurrence and development of CRC, miRNA expression profiling may be a new alternative approach to monitor the transition of colorectal adenoma to carcinoma [170]. This may also help to overcome the issues with traditional ways of monitoring or diagnosing the progression of CRC through colonoscopy and/or fecal occult blood tests, as these methods are expensive, invasive, and not sensitive [170-172]. Recent studies have shown that expression levels of miR-21, $m i R-106 a, m i R-7, m i R-17, m i R-21, m i R-92 a, m i R-96, m i R-134$, and $m i R-196 a$ are significantly upregulated in the stool samples of CRC patients [173,174]. Intriguingly, the expression levels of some of these miRNAs were found to be even higher in patients with later tumorlymph node metastatic (TNM) carcinoma stages compared to those with adenomas [174]. Furthermore, some miRNAs (miR-9, miR-138, miR-143, miR-127-5p, miR-29b, miR-938, and $m i R-222)$ were significantly downregulated in the stool samples of colorectal cancer patients [174]. Implementing screening of these miRNAs for clinical diagnostic purposes would provide a promising non-invasive approach to detect CRC in the future.

\section{Role of Oxidative Stress and Antioxidants in CRC Progression}

The link between oxidative stress and colorectal cancer has been studied vigorously over the past decade. Oxidative stress is an imbalance of oxidants or reactive oxygen species (ROS) and antioxidant defense in the cell. It can be produced both intracellularly or extracellularly $[175,176]$. Intracellularly, the production of ROS is dependent on almost all enzymes that use molecular oxygen as a substrate like NADPH oxidase, microsomal cytochrome P450, peroxisomes, xanthine oxidase, cytokines, and growth factors. Besides ROS, reactive nitrogen species (RNS) could also contribute to redox signaling in cells. Several external factors such as UV light, smoking, air pollution, stress, or medication could also enhance the free radical formation [177]. At lower concentrations, these free radicals are necessary for the host defense mechanism and tissue repair mechanism [178]. However, when present at higher concentrations, they may lead to mutations in the DNA or neoplastic transformation, causing cellular damage $[179,180]$. The evolution of cancer has been correlated with oxidative stress-induced DNA damage and genetic instability [21]. Superoxide anion, hydroxyl radical, hydroperoxyl radical, and hydrogen peroxide from different intracellular metabolic pathways majorly contribute to intracellular ROS levels [181], leading to lipid peroxidation, protein oxidation, or DNA damage; eventually 
progressing to the development of cancer [182-184]. In DNA, ROS can induce single or double-strand breaks, or nucleotide base modification [24]. The final products of lipid peroxidation such as malondialdehyde (MDA) and 4-hydroxy-2-nonenal (4-HNE), can also react with the DNA bases to give rise to DNA adducts, which could promote CRC carcinogenesis [20]. DNA repair proteins such as glycosylases, endo and exonucleases, DNA ligases, and DNA polymerases contribute to the removal of the oxidized base pairs by either base excision repair (BER) or MMR. The damage caused by 5 -fluorouracil (5-FU), a common chemotherapeutic drug used for CRC treatment, is also repaired by BER or MMR [128,185,186], which represents the patients DNA repair capacity (DRC) determining their response to chemotherapy and CRC prognosis [128,185,186]. Studies have been conducted to determine the use of BER-DRC as a prognostic marker to 5-FU therapy [128]. However, evidence suggests that these DNA repair proteins may also be disrupted due to higher levels of ROS [187] or subjected to altered activity due to DNA polymorphisms [188].

Cells can react to oxidative stress in different ways; creating stress survival strategies if the exposure is limited. However, if the cell goes through prolonged perturbation against the natural strategies for this balance, the cells either become apoptotic or undergo necrotic cell death $[189,190]$. There is an involvement of several ROS metabolizing enzymes such as catalase, peroxiredoxins, glutathione peroxidase, superoxide dismutase, glutathione reductase, and thioredoxin reductase to maintain pro-oxidants: antioxidants balance [191]. As mentioned in the previous section, genes encoding for some of these proteins, GPX1, PRDX1, and SOD, are known to be upregulated in CRC samples [92,105-107,116]. Nonenzymatic antioxidants such as glutathione (GSH), coenzyme Q, uric acid, polyphenols, and melatonin may also work in a complex system with enzymatic antioxidants to reduce ROS levels [183]. Antioxidants such as gamma-tocopherol, carotenoids, tocotrienols, aspirin, and vitamin C have also been linked to a reduced risk of CRC $[175,192,193]$. For the beneficial effects of such antioxidants in preventing carcinogenesis, efforts are being made to identify their source and mode of action [175].

For years, it has been well established that oxidative stress is one of the major contributors to CRC progression [194]. However, previous work does not contribute to affirming the role of antioxidants in reducing oxidative stress in human subjects with a high risk of CRC [175]. It is evident that not all compounds with antioxidant capacity could reduce the risk of CRC progression; however, critical evaluation of optimal food antioxidants for preventing CRC is crucial. Only a few studies have been conducted to detect increased levels of oxidative stress markers and antioxidants in the blood of patients with CRC [194-197]. Several studies have been conducted to detect oxidized nucleotides in the urine sample of patients diagnosed with breast and lung cancer, atherosclerosis, and diabetes [198-204]. DNA oxidation, measured as urinary excretion of 7,8-dihydroxy-8-oxoguanosine (8oxoGuo) has been proven to be a prognostic tool for these diseases [201-204]. Further, detection of 8oxodG, has recently been emphasized as a marker for a high level of RNA oxidation in neurodegeneration, breast cancer, and diabetes [198-200]. Implying that the findings from these studies would be interesting for the development of new diagnostic tools for CRC development and progression. Studies in small populations have shown that the measurement of reactive oxygen metabolites or the ferric reducing ability of plasma as ROS production biomarkers could be promising diagnostic tools [194,195]. Malondialdehyde, 4-hydroxy-2-nonenal (4-HNE), and isoprostanes, which are the final products of polyunsaturated fatty acids are currently being used as biomarkers for CRC detection [196]. However, long-term follow-up remains a consistent issue in human subject trials [194]. It is essential to emphasize longer follow-up durations and repeated measurements of both ROS and antioxidant levels in larger populations to explore their use in clinical practice. Substantial work also needs to be done to understand the complex network governing DNA damage, and genotoxic effects of ROS in the progression of CRC. 


\section{Apoptosis and CRC Progression}

Apoptosis is the process of programmed cell death or cell suicide that maintains the cell population in the tissue [205]. It helps to get rid of unwanted cells during developmental stages or the cells with damaged DNA or cytoskeleton which are beyond repair in adults [206]. If apoptosis is for some reason interrupted, inappropriate apoptosis can lead to uncontrolled cell division and the subsequent development of a tumor. Its ability to modulate the life or death of a cell is recognized for its immense potential to be used as a therapeutic target. In normal colon epithelial cells, to preserve the structure, a balance is maintained between apoptosis at the top of the crypts and cell proliferation at the base of crypts [207]. The increased apoptosis rate at the bottom of the crypts and higher proliferation rate at the top of crypts in adenomas hinder the colonic epithelium homeostasis that is correlated with the progression of CRC. However, in carcinomas, apoptosis is not specifically localized [208]. During the evolution of colon cancer from adenomas to carcinoma, differential expression of many apoptosis-related proteins is observed, indicating the importance of apoptosis in colorectal carcinogenesis [209]. Tumor suppressor genes (APC or TP53) and oncogenes (KRAS or BRAF) work together in apoptotic failure and progression of CRC $[206,210,211]$. These genes may sometimes also regulate sporadic and hereditary CRC [52]. Up to 70\% of CRC cases show either mutation or deletion in tumor suppressor genes including TP53 [209]. Activated p53 can upregulate the expression of genes that encode pro-apoptotic BCL-2 proteins such as Noxa, PUMA, Bax, and some death receptors such as Fas, PIDD, DR5 [211]. When a ligand binds to death receptors such as Fas and DR5, it initiates the activation of the caspases, which further turns on the apoptotic cell death pathway [212]. The KRAS gene is another commonly mutated gene present in approximately $40 \%$ of CRC cases [213]. Interestingly, the KRAS mutation is more frequently found in African Americans than Caucasian colonic tumors [214], but the rate of BRAF mutation is twice as much in whites compared to Asians or African Americans, with Asians having the least rate of occurrence [214,215]. Currently, the mediators BCL-2, DR-5, and caspases are being used as targets for testing the efficacy of drugs for CRC treatment in clinical and pre-clinical trials [216]. However, dysregulated apoptosis in the colonic epithelial cells also contributes to radiation and chemotherapy resistance [207]. Apoptosis is an important regulatory process and pro-apoptotic proteins such as the BCL-2 family of proteins may function as monitors of damage signals, it would be beneficial to further explore their potential as logical targets to overcoming drug resistance.

\section{Conclusions}

Colorectal cancer remains one of the leading causes of mortality due to cancer. Despite the decline in CRC cases in the U.S. over the last few decades, some ethnic groups still have a higher incidence and mortality rate. Knowledge of CRC health disparity among different ethnicities is crucial to identify and improve the potential risk factors for CRC. Very few studies have been conducted to elucidate the molecular basis of CRC carcinogenesis in different ethnic groups. One of the major contributors to CRC carcinogenesis is oxidative stress. Here, we have elucidated the importance of oxidative stress in CRC progression, and the function of antioxidants as a preventive measure. We have also focused on genes that may contribute to the development and progression of CRC, as they could be considered biomarkers and therapeutic targets. Since CRC is a multifactorial disease, a better understanding of molecular pathways involved in CRC initiation and progression is vital for the prognosis and treatment of CRC. Conducting further studies in minority groups to identify genetic markers for CRC predisposition is critical and would be an interesting area to explore in the future.

Author Contributions: Literature survey and original draft preparation, U.B. and A.R.P.; reviewing and editing, A.K. and S.R. All authors have read and agreed to the published version of the manuscript. 
Funding: This work was supported by Grant 5U54MD007592 Pilot Project (SR) from the National Institute on Minority Health and Health Disparities (NIMHD), a component of the National Institutes of Health (NIH).

Institutional Review Board Statement: Not applicable.

Informed Consent Statement: Not applicable.

Data Availability Statement: Not applicable.

Conflicts of Interest: The authors declare no conflict of interest.

\section{References}

1. Cancer-WHOIWorld Health Organization. Available online: https://www.who.int/news-room/fact-sheets/detail/cancer (accessed on 16 November 2020).

2. Bray, F.; Ferlay, J.; Soerjomataram, I.; Siegel, R.L.; Torre, L.A.; Jemal, A. Global cancer statistics 2018: GLOBOCAN estimates of incidence and mortality worldwide for 36 cancers in 185 countries. CA Cancer J. Clin. 2018, 68, 394-424. [CrossRef]

3. Garcia, S.; Pruitt, S.L.; Singal, A.G.; Murphy, C.C. Colorectal cancer incidence among Hispanics and non-Hispanic Whites in the United States. Cancer Causes Control 2018, 29, 1039-1046. [CrossRef]

4. Bailey, C.E.; Hu, C.Y.; You, Y.N.; Bednarski, B.K.; Rodriguez-Bigas, M.A.; Skibber, J.M.; Cantor, S.B.; Chang, G.J. Increasing disparities in the age-related incidences of colon and rectal cancers in the United States, 1975-2010. JAMA Surg. 2015. [CrossRef] [PubMed]

5. Ahmed, M. Colon Cancer: A Clinician's Perspective in 2019. Gastroenterol. Res. 2020, 13, 1-10. [CrossRef] [PubMed]

6. La Vecchia, S.; Sebastián, C. Metabolic pathways regulating colorectal cancer initiation and progression. Semin. Cell Dev. Biol. 2020, 98, 63-70. [CrossRef]

7. White, A.; Vernon, S.W.; Franzini, L.; Du, X.L. Racial disparities in colorectal cancer survival. Cancer 2010, 116, 4622-4631. [CrossRef]

8. Warren Andersen, S.; Blot, W.J.; Lipworth, L.; Steinwandel, M.; Murff, H.J.; Zheng, W. Association of Race and Socioeconomic Status With Colorectal Cancer Screening, Colorectal Cancer Risk, and Mortality in Southern US Adults. JAMA Netw. Open 2019, 2, e1917995. [CrossRef] [PubMed]

9. May, F.P.; Glenn, B.A.; Crespi, C.M.; Ponce, N.; Spiegel, B.M.R.; Bastani, R. Decreasing Black-White Disparities in Colorectal Cancer Incidence and Stage at Presentation in the United States. Cancer Epidemiol. Biomark. Prev. 2017, 26, 762-768. [CrossRef]

10. Hong, S.N. Genetic and epigenetic alterations of colorectal cancer. Intest. Res. 2018, 16, 327-337. [CrossRef]

11. Loomans-Kropp, H.A.; Umar, A. Increasing Incidence of Colorectal Cancer in Young Adults. J. Cancer Epidemiol. 2019, 2019, 9841295. [CrossRef]

12. Jia, Y.; Guo, M. Epigenetic changes in colorectal cancer. Chin. J. Cancer 2013, 32, 21-30. [CrossRef]

13. Peng, Y.; Croce, C.M. The role of microRNAs in human cancer. Signal Transduct. Target. Ther. 2016, 1, 1-9. [CrossRef] [PubMed]

14. Zhou, K.; Liu, M.; Cao, Y. New Insight into microRNA Functions in Cancer: Oncogene-microRNA-Tumor Suppressor Gene Network. Front. Mol. Biosci. 2017, 4, 46. [CrossRef] [PubMed]

15. Ding, L.; Lan, Z.; Xiong, X.; Ao, H.; Feng, Y.; Gu, H.; Yu, M.; Cui, Q. The Dual Role of MicroRNAs in Colorectal Cancer Progression. Int. J. Mol. Sci. 2018, 19, 2791. [CrossRef] [PubMed]

16. Jung, G.; Hernández-Illán, E.; Moreira, L.; Balaguer, F.; Goel, A. Epigenetics of colorectal cancer: Biomarker and therapeutic potential. Nat. Rev. Gastroenterol. Hepatol. 2020, 17, 111-130. [CrossRef]

17. Lu, Y.; Kweon, S.S.; Tanikawa, C.; Jia, W.H.; Xiang, Y.B.; Cai, Q.; Zeng, C.; Schmit, S.L.; Shin, A.; Matsuo, K.; et al. Large-Scale Genome-Wide Association Study of East Asians Identifies Loci Associated With Risk for Colorectal Cancer. Gastroenterology 2019, 156, 1455-1466. [CrossRef]

18. Lu, A.G.; Feng, H.; Wang, P.X.Z.; Han, D.P.; Chen, X.H.; Zheng, M.H. Emerging roles of the ribonucleotide reductase M2 in colorectal cancer and ultraviolet-induced DNA damage repair. World J. Gastroenterol. 2012. [CrossRef]

19. Ding, X.; Duan, H.; Luo, H. Identification of Core Gene Expression Signature and Key Pathways in Colorectal Cancer. Front. Genet. 2020. [CrossRef]

20. Perše, M. Oxidative Stress in the Pathogenesis of Colorectal Cancer: Cause or Consequence? BioMed Res. Int. 2013, 2013, 725710. [CrossRef]

21. Reuter, S.; Gupta, S.C.; Chaturvedi, M.M.; Aggarwal, B.B. Oxidative stress, inflammation, and cancer: How are they linked? Free Radic. Biol. Med. 2010, 49, 1603-1616. [CrossRef]

22. Kovács, I.; Horváth, M.; Lányi, Á.; Petheő, G.L.; Geiszt, M. Reactive oxygen species-mediated bacterial killing by B lymphocytes. J. Leukoc. Biol. 2015, 97, 1133-1137. [CrossRef] [PubMed]

23. Kowaltowski, A.J.; Vercesi, A.E. Mitochondrial damage induced by conditions of oxidative stress. Free Radic. Biol. Med. 1999, 26, 463-471. [CrossRef]

24. Sreevalsan, S.; Safe, S. Reactive Oxygen Species and Colorectal Cancer. Curr. Colorectal Cancer Rep. 2013, 9, 350-357. [CrossRef] 
25. Ahmad, R.; Vaali-Mohammed, M.; Elwatidy, M.; Al-Obeed, O.; Al-Khayal, K.; Eldehna, M.W.; Abdel-Aziz, A.H.; Alafeefy, A.; Abdulla, M. Induction of ROS-mediated cell death and activation of the JNK pathway by a sulfonamide derivative. Int. J. Mol. Med. 2019, 44, 1552-1562. [CrossRef] [PubMed]

26. Lin, S.; Li, Y.; Zamyatnin, A.A., Jr.; Werner, J.; Bazhin, A.V. Reactive oxygen species and colorectal cancer. J. Cell Physiol. 2018, 233, 5119-5132. [CrossRef]

27. Jackson, C.S.; Oman, M.; Patel, A.M.; Vega, K.J. Health disparities in colorectal cancer among racial and ethnic minorities in the United States. J. Gastrointest. Oncol. 2016, 7, S32-S43. [CrossRef] [PubMed]

28. Rahman, R.; Schmaltz, C.; Jackson, C.S.; Simoes, E.J.; Jackson-Thompson, J.; Ibdah, J.A. Increased risk for colorectal cancer under age 50 in racial and ethnic minorities living in the United States. Cancer Med. 2015, 4, 1863-1870. [CrossRef]

29. Pinheiro, P.S.; Callahan, K.E.; Siegel, R.L.; Jin, H.; Morris, C.R.; Trapido, E.J.; Gomez, S.L. Cancer Mortality in Hispanic Ethnic Groups. Cancer Epidemiol. Biomark. Prev. 2017, 26, 376-382. [CrossRef]

30. Wang, D.Y.; Thrift, A.P.; Zarrin-Khameh, N.; Wichmann, A.; Armstrong, G.N.; Thompson, P.A.; Bondy, M.L.; Musher, B.L. Rising Incidence of Colorectal Cancer Among Young Hispanics in Texas. J. Clin. Gastroenterol. 2017, 51, 34-42. [CrossRef]

31. American Cancer Society. Colorectal Cancer Facts E Figures 2020-2022; American Cancer Society Inc: Atlanta, GA, USA, 2020; pp. $1-42$.

32. Jackson, C.S.; Vega, K.J. Health Disparities in Col orectal Cancer among African and Hispanic Americans in the United States. J. Adenocarcinoma 2016, 1, 1-9. [CrossRef]

33. Byrd, T.L.; Calderón-Mora, J.; Salaiz, R.; Shokar, N.K. Barriers and Facilitators to Colorectal Cancer Screening Within a Hispanic Population. Hisp. Health Care Int. 2018, 17, 23-29. [CrossRef] [PubMed]

34. Rawla, P.; Sunkara, T.; Barsouk, A. Epidemiology of colorectal cancer: Incidence, mortality, survival, and risk factors. Gastroenterol. Rev. Gastroenterol. 2019, 14, 89-103. [CrossRef] [PubMed]

35. Abancens, M.; Bustos, V.; Harvey, H.; McBryan, J.; Harvey, B.J. Sexual Dimorphism in Colon Cancer. Front. Oncol. 2020, 10, 2765. [CrossRef] [PubMed]

36. Cai, Y.; Rattray, N.J.W.; Zhang, Q.; Mironova, V.; Santos-Neto, A.; Hsu, K.-S.; Rattray, Z.; Cross, J.R.; Zhang, Y.; Paty, P.B.; et al. Sex Differences in Colon Cancer Metabolism Reveal A Novel Subphenotype. Sci. Rep. 2020, 10, 4905. [CrossRef]

37. Sun, M.; Wang, Y.; Sundquist, J.; Sundquist, K.; Ji, J. Temporal Trends of Sex Disparity in Incidence and Survival of Colorectal Cancer: Variations by Anatomical Site and Age at Diagnosis. Clin. Epidemiol. 2020, 12, 73-81. [CrossRef]

38. Bläker, H.; Alwers, E.; Arnold, A.; Herpel, E.; Tagscherer, K.E.; Roth, W.; Jansen, L.; Walter, V.; Kloor, M.; Chang-Claude, J.; et al. The Association Between Mutations in BRAF and Colorectal Cancer-Specific Survival Depends on Microsatellite Status and Tumor Stage. Clin. Gastroenterol. Hepatol. 2019, 17, 455-462.e6. [CrossRef]

39. Wang, X.; Ji, P.; Zhang, Y.; LaComb, J.F.; Tian, X.; Li, E.; Williams, J.L. Aberrant DNA Methylation: Implications in Racial Health Disparity. PLoS ONE 2016, 11, e0153125. [CrossRef]

40. Muller, C.; Ihionkhan, E.; Stoffel, E.M.; Kupfer, S.S. Disparities in Early-Onset Colorectal Cancer. Cells 2021, 10, 1018. [CrossRef]

41. Benninghoff, A.D.; Hintze, K.J.; Monsanto, S.P.; Rodriguez, D.M.; Hunter, A.H.; Phatak, S.; Pestka, J.J.; Van Wettere, A.J.; Ward, R.E. Consumption of the Total Western Diet Promotes Colitis and Inflammation-Associated Colorectal Cancer in Mice. Nutrients 2020, 12, 544. [CrossRef]

42. Gonzales, M.; Nelson, H.; Rhyne, R.L.; Stone, S.N.; Hoffman, R.M. Surveillance of colorectal cancer screening in new Mexico hispanics and non-Hispanic whites. J. Community Health 2012, 37, 1279-1288. [CrossRef]

43. Guo, X.-F.; Wang, J.; Yu, S.-J.; Song, J.; Ji, M.-Y.; Zhang, J.-X.; Cao, Z.; Wang, J.; Dong, W.-G. Meta-analysis of the ADH1B and ALDH2 polymorphisms and the risk of colorectal cancer in East Asians. Intern. Med. 2013, 52, 2693-2699. [CrossRef] [PubMed]

44. Peng, G.-S.; Chen, Y.-C.; Tsao, T.-P.; Wang, M.-F.; Yin, S.-J. Pharmacokinetic and pharmacodynamic basis for partial protection against alcoholism in Asians, heterozygous for the variant ALDH2*2 gene allele. Pharmacogenet. Genom. 2007, 17, 845-855. [CrossRef] [PubMed]

45. Gao, C.-M.; Takezaki, T.; Wu, J.-Z.; Zhang, X.-M.; Cao, H.-X.; Ding, J.-H.; Liu, Y.-T.; Li, S.-P.; Cao, J.; Matsuo, K.; et al. Polymorphisms of alcohol dehydrogenase 2 and aldehyde dehydrogenase 2 and colorectal cancer risk in Chinese males. World J. Gastroenterol. 2008, 14, 5078-5083. [CrossRef] [PubMed]

46. Rossi, M.; Anwar, M.J.; Usman, A.; Keshavarzian, A.; Bishehsari, F. Colorectal cancer and alcohol consumption-populations to molecules. Cancers 2018, 10, 38. [CrossRef]

47. Seeff, L.C.; Nadel, M.R.; Klabunde, C.N.; Thompson, T.; Shapiro, J.A.; Vernon, S.W.; Coates, R.J. Patterns and predictors of colorectal cancer test use in the adult U.S. population. Cancer 2004, 100, 2093-2103. [CrossRef]

48. Carcaise-Edinboro, P.; Bradley, C.J. Influence of patient-provider communication on colorectal cancer screening. Med. Care 2008, 46, 738-745. [CrossRef]

49. Merchant, J.L.; Omary, M.B. Underrepresentation of underrepresented minorities in academic medicine: The need to enhance the pipeline and the pipe. Gastroenterology 2010, 138, 13-19. [CrossRef]

50. Abreu, M.T.; Okolo, P.I., 3rd. Re: Underrepresentation of underrepresented minorities in academic medicine. Gastroenterology 2010, 138, 19-26.e1-3.

51. Gupta, S.; Halm, E.A.; Rockey, D.C.; Hammons, M.; Koch, M.; Carter, E.; Valdez, L.; Tong, L.; Ahn, C.; Kashner, M.; et al. Comparative effectiveness of fecal immunochemical test outreach, colonoscopy outreach, and usual care for boosting colorectal cancer screening among the underserved: A randomized clinical trial. JAMA Intern. Med. 2013, 173, 1725-1732. [CrossRef] 
52. Asghari, M.; Abazari, M.F.; Bokharaei, H.; Aleagha, M.N.; Poortahmasebi, V.; Askari, H.; Torabinejad, S.; Ardalan, A.; Negaresh, N.; Ataei, A.; et al. Key genes and regulatory networks involved in the initiation, progression and invasion of colorectal cancer. Futur. Sci. OA 2018, 4, FSO278. [CrossRef]

53. Hong, B.S.; Cho, J.H.; Kim, H.; Choi, E.J.; Rho, S.; Kim, J.; Kim, J.H.; Choi, D.S.; Kim, Y.K.; Hwang, D.; et al. Colorectal cancer cell-derived microvesicles are enriched in cell cycle-related mRNAs that promote proliferation of endothelial cells. BMC Genom. 2009, 10, 556. [CrossRef]

54. Li, J.; Wang, Y.; Wang, X.; Yang, Q. CDK1 and CDC20 overexpression in patients with colorectal cancer are associated with poor prognosis: Evidence from integrated bioinformatics analysis. World J. Surg. Oncol. 2020, 18, 50. [CrossRef] [PubMed]

55. Gan, Y.; Li, Y.; Li, T.; Shu, G.; Yin, G. CCNA2 acts as a novel biomarker in regulating the growth and apoptosis of colorectal cancer. Cancer Manag. Res. 2018. [CrossRef] [PubMed]

56. Iacopetta, B.; Russo, A.; Bazan, V.; Dardanoni, G.; Gebbia, N.; Soussi, T.; Kerr, D.; Elsaleh, H.; Soong, R.; Kandioler, D.; et al. Functional categories of TP53 mutation in colorectal cancer: Results of an International Collaborative Study. Ann. Oncol. 2006. [CrossRef] [PubMed]

57. Slattery, M.L.; Mullany, L.E.; Wolff, R.K.; Sakoda, L.C.; Samowitz, W.S.; Herrick, J.S. The p53-signaling pathway and colorectal cancer: Interactions between downstream p53 target genes and miRNAs. Genomics 2019. [CrossRef]

58. Coss, A.; Tosetto, M.; Fox, E.J.; Sapetto-Rebow, B.; Gorman, S.; Kennedy, B.N.; Lloyd, A.T.; Hyland, J.M.; O’Donoghue, D.P.; Sheahan, K.; et al. Increased topoisomerase II $\alpha$ expression in colorectal cancer is associated with advanced disease and chemotherapeutic resistance via inhibition of apoptosis. Cancer Lett. 2009. [CrossRef]

59. Yu, C.; Chen, F.; Jiang, J.; Zhang, H.; Zhou, M. Screening key genes and signaling pathways in colorectal cancer by integrated bioinformatics analysis. Mol. Med. Rep. 2019. [CrossRef]

60. Cai, J.; Wang, H.; Jiao, X.; Huang, R.; Qin, Q.; Zhang, J.; Chen, H.; Feng, D.; Tian, X.; Wang, H. The RNA-Binding Protein HuR Confers Oxaliplatin Resistance of Colorectal Cancer By Upregulating CDC6. Mol. Cancer Ther. 2019, 18, 1243-1254. [CrossRef]

61. Han, G.; Wei, Z.; Cui, H.; Zhang, W.; Wei, X.; Lu, Z.; Bai, X. NUSAP1 gene silencing inhibits cell proliferation, migration and invasion through inhibiting DNMT1 gene expression in human colorectal cancer. Exp. Cell Res. 2018. [CrossRef]

62. Lin, K.; Zhu, X.; Luo, C.; Bu, F.; Zhu, J.; Zhu, Z. Data mining combined with experiments to validate CEP55 as a prognostic biomarker in colorectal cancer. Immun. Inflamm. Dis. 2021, 9, 167-182. [CrossRef]

63. Liu, X.; Liu, X.; Qiao, T.; Chen, W. Identification of crucial genes and pathways associated with colorectal cancer by bioinformatics analysis. Oncol. Lett. 2020, 19, 1881-1889. [CrossRef]

64. Carvalhal, S.; Ribeiro, S.A.; Arocena, M.; Kasciukovic, T.; Temme, A.; Koehler, K.; Huebner, A.; Griffis, E.R. The nucleoporin ALADIN regulates Aurora A localization to ensure robust mitotic spindle formation. Mol. Biol. Cell 2015, 26, 3424-3438. [CrossRef] [PubMed]

65. Carvalho, B.; Postma, C.; Mongera, S.; Hopmans, E.; Diskin, S.; van de Wiel, M.A.; van Criekinge, W.; Thas, O.; Matthäi, A.; Cuesta, M.A.; et al. Multiple putative oncogenes at the chromosome 20q amplicon contribute to colorectal adenoma to carcinoma progression. Gut 2009, 58, 79-89. [CrossRef] [PubMed]

66. Casorzo, L.; Dell'Aglio, C.; Sarotto, I.; Risio, M. Aurora kinase A gene copy number is associated with the malignant transformation of colorectal adenomas but not with the serrated neoplasia progression. Hum. Pathol. 2015, 46, 411-418. [CrossRef] [PubMed]

67. Bolanos-Garcia, V.M.; Kiyomitsu, T.; D’Arcy, S.; Chirgadze, D.Y.; Grossmann, J.G.; Matak-Vinkovic, D.; Venkitaraman, A.R.; Yanagida, M.; Robinson, C.V.; Blundell, T.L. The crystal structure of the N-terminal region of BUB1 provides insight into the mechanism of BUB1 recruitment to kinetochores. Structure 2009, 17, 105-116. [CrossRef] [PubMed]

68. Cahill, D.P.; Lengauer, C.; Yu, J.; Riggins, G.J.; Willson, J.K.; Markowitz, S.D.; Kinzler, K.W.; Vogelstein, B. Mutations of mitotic checkpoint genes in human cancers. Nature 1998, 392, 300-303. [CrossRef] [PubMed]

69. Beamish, H.; de Boer, L.; Giles, N.; Stevens, F.; Oakes, V.; Gabrielli, B. Cyclin A/cdk2 regulates adenomatous polyposis coli-dependent mitotic spindle anchoring. J. Biol. Chem. 2009, 284, 29015-29023. [CrossRef]

70. Hochegger, H.; Takeda, S.; Hunt, T. Cyclin-dependent kinases and cell-cycle transitions: Does one fit all? Nat. Rev. Mol. Cell Biol. 2008, 9, 910-916. [CrossRef]

71. McArdel, S.L.; Terhorst, C.; Sharpe, A.H. Roles of CD48 in regulating immunity and tolerance. Clin. Immunol. 2016, 164, 10-20. [CrossRef]

72. Horst, D.; Budczies, J.; Brabletz, T.; Kirchner, T.; Hlubek, F. Invasion associated up-regulation of nuclear factor $\kappa B$ target genes in colorectal cancer. Cancer 2009, 115, 4946-4958. [CrossRef]

73. Borlado, L.R.; Méndez, J. CDC6: From DNA replication to cell cycle checkpoints and oncogenesis. Carcinogenesis 2008, 29, 237-243. [CrossRef] [PubMed]

74. Santamaría, D.; Barrière, C.; Cerqueira, A.; Hunt, S.; Tardy, C.; Newton, K.; Cáceres, J.F.; Dubus, P.; Malumbres, M.; Barbacid, M. Cdk1 is sufficient to drive the mammalian cell cycle. Nature 2007. [CrossRef] [PubMed]

75. Xue, X.; Ramakrishnan, S.K.; Weisz, K.; Triner, D.; Xie, L.; Attili, D.; Pant, A.; Győrffy, B.; Zhan, M.; Carter-Su, C.; et al. Iron Uptake via DMT1 Integrates Cell Cycle with JAK-STAT3 Signaling to Promote Colorectal Tumorigenesis. Cell Metab. 2016. [CrossRef] [PubMed]

76. Fabbro, M.; Zhou, B.-B.; Takahashi, M.; Sarcevic, B.; Lal, P.; Graham, M.E.; Gabrielli, B.G.; Robinson, P.J.; Nigg, E.A.; Ono, Y.; et al. Cdk1/Erk2- and Plk1-dependent phosphorylation of a centrosome protein, Cep55, is required for its recruitment to midbody and cytokinesis. Dev. Cell 2005, 9, 477-488. [CrossRef] [PubMed] 
77. Feijoo, C.; Hall-Jackson, C.; Wu, R.; Jenkins, D.; Leitch, J.; Gilbert, D.M.; Smythe, C. Activation of mammalian Chk1 during DNA replication arrest: A role for Chk1 in the intra-S phase checkpoint monitoring replication origin firing. J. Cell Biol. 2001, 154, 913-923. [CrossRef] [PubMed]

78. Stawinska, M.; Cygankiewicz, A.; Trzcinski, R.; Mik, M.; Dziki, A.; Krajewska, W.M. Alterations of Chk1 and Chk2 expression in colon cancer. Int. J. Colorectal Dis. 2008, 23, 1243-1249. [CrossRef] [PubMed]

79. Rogers, R.F.; Walton, M.I.; Cherry, D.L.; Collins, I.; Clarke, P.A.; Garrett, M.D.; Workman, P. CHK1 Inhibition Is Synthetically Lethal with Loss of B-Family DNA Polymerase Function in Human Lung and Colorectal Cancer Cells. Cancer Res. 2020, 80, 1735-1747. [CrossRef]

80. Chen, H.; Liu, Y.; Jiang, C.-J.; Chen, Y.-M.; Li, H.; Liu, Q.-A. Calcium-Activated Chloride Channel A4 (CLCA4) Plays Inhibitory Roles in Invasion and Migration Through Suppressing Epithelial-Mesenchymal Transition via PI3K/AKT Signaling in Colorectal Cancer. Med. Sci. Monit. 2019, 25, 4176-4185. [CrossRef]

81. Jin, L.; Batra, S.; Douda, D.N.; Palaniyar, N.; Jeyaseelan, S. CXCL1 Contributes to Host Defense in Polymicrobial Sepsis via Modulating T Cell and Neutrophil Functions. J. Immunol. 2014, 193, 3549-3558. [CrossRef]

82. Sawant, K.V.; Poluri, K.M.; Dutta, A.K.; Sepuru, K.M.; Troshkina, A.; Garofalo, R.P.; Rajarathnam, K. Chemokine CXCL1 mediated neutrophil recruitment: Role of glycosaminoglycan interactions. Sci. Rep. 2016, 6, 33123. [CrossRef]

83. Wang, D.; Wang, H.; Brown, J.; Daikoku, T.; Ning, W.; Shi, Q.; Richmond, A.; Strieter, R.; Dey, S.K.; DuBois, R.N. CXCL1 induced by prostaglandin E2 promotes angiogenesis in colorectal cancer. J. Exp. Med. 2006, 203, 941-951. [CrossRef] [PubMed]

84. Wuyts, A.; Govaerts, C.; Struyf, S.; Lenaerts, J.P.; Put, W.; Conings, R.; Proost, P.; Van Damme, J. Isolation of the CXC chemokines ENA-78, GRO alpha and GRO gamma from tumor cells and leukocytes reveals NH2-terminal heterogeneity. Functional comparison of different natural isoforms. Eur. J. Biochem. 1999, 260, 421-429. [CrossRef] [PubMed]

85. Ruan, G.-T.; Gong, Y.-Z.; Liao, X.-W.; Wang, S.; Huang, W.; Wang, X.-K.; Zhu, G.-Z.; Liao, C.; Gao, F. Diagnostic and prognostic values of C-X-C motif chemokine ligand 3 in patients with colon cancer. Oncol. Rep. 2019, 42, 1996-2008. [CrossRef] [PubMed]

86. Gibbons, D.; Fleming, P.; Virasami, A.; Michel, M.-L.; Sebire, N.J.; Costeloe, K.; Carr, R.; Klein, N.; Hayday, A. Interleukin-8 (CXCL8) production is a signatory T cell effector function of human newborn infants. Nat. Med. 2014, 20, 1206-1210. [CrossRef]

87. Brennan, K.; Zheng, J. Interleukin 8. In xPharm: The Comprehensive Pharmacology Reference; Elsevier: New York, NY, USA, 2007; pp. 1-4. ISBN 978-0-08-055232-3.

88. Bie, Y.; Ge, W.; Yang, Z.; Cheng, X.; Zhao, Z.; Li, S.; Wang, W.; Wang, Y.; Zhao, X.; Yin, Z.; et al. The Crucial Role of CXCL8 and Its Receptors in Colorectal Liver Metastasis. Dis. Markers 2019, 2019, 8023460. [CrossRef]

89. Zjablovskaja, P.; Kardosova, M.; Danek, P.; Angelisova, P.; Benoukraf, T.; Wurm, A.A.; Kalina, T.; Sian, S.; Balastik, M.; Delwel, R.; et al. EVI2B is a $\mathrm{C} / \mathrm{EBP} \alpha$ target gene required for granulocytic differentiation and functionality of hematopoietic progenitors. Cell Death Differ. 2017, 24, 705-716. [CrossRef]

90. Yuan, Y.; Chen, J.; Wang, J.; Xu, M.; Zhang, Y.; Sun, P.; Liang, L. Identification Hub Genes in Colorectal Cancer by Integrating Weighted Gene Co-Expression Network Analysis and Clinical Validation in vivo and vitro. Front. Oncol. 2020. [CrossRef]

91. Lubos, E.; Loscalzo, J.; Handy, D.E. Glutathione peroxidase-1 in health and disease: From molecular mechanisms to therapeutic opportunities. Antioxid. Redox Signal. 2011, 15, 1957-1997. [CrossRef]

92. Janssen, A.M.L.; Bosman, C.B.; Sier, C.F.M.; Griffioen, G.; Kubben, F.J.G.M.; Lamers, C.B.H.W.; Van Krieken, J.H.J.M.; Van de Velde, C.J.H.; Verspaget, H.W. Superoxide dismutases in relation to the overall survival of colorectal cancer patients. Br. J. Cancer 1998, 78, 1051-1057. [CrossRef]

93. Scielzo, C.; Bertilaccio, M.T.S.; Simonetti, G.; Dagklis, A.; Ten Hacken, E.; Fazi, C.; Muzio, M.; Caiolfa, V.; Kitamura, D.; Restuccia, U.; et al. HS1 has a central role in the trafficking and homing of leukemic B cells. Blood 2010, 116, 3537-3546. [CrossRef]

94. Cavnar, P.J.; Mogen, K.; Berthier, E.; Beebe, D.J.; Huttenlocher, A. The actin regulatory protein HS1 interacts with Arp2/3 and mediates efficient neutrophil chemotaxis. J. Biol. Chem. 2012, 287, 25466-25477. [CrossRef] [PubMed]

95. Benhamou, L.E.; Watanabe, T.; Kitamura, D.; Cazenave, P.A.; Sarthou, P. Signaling properties of anti-immunoglobulin-resistant variants of WEHI-231 B lymphoma cells. Eur. J. Immunol. 1994, 24, 1993-1999. [CrossRef] [PubMed]

96. Zhou, F.; Tang, D.; Xu, Y.; He, H.; Wu, Y.; Lin, L.; Dong, J.; Tan, W.; Dai, Y. Identification of microRNAs and their Endonucleolytic Cleavaged target mRNAs in colorectal cancer. BMC Cancer 2020, 20, 242. [CrossRef] [PubMed]

97. Ji, W.; Luo, Y.; Ahmad, E.; Liu, S.-T. Direct interactions of mitotic arrest deficient 1 (MAD1) domains with each other and MAD2 conformers are required for mitotic checkpoint signaling. J. Biol. Chem. 2018, 293, 484-496. [CrossRef]

98. Shi, G.; Wang, Y.; Zhang, C.; Zhao, Z.; Sun, X.; Zhang, S.; Fan, J.; Zhou, C.; Zhang, J.; Zhang, H.; et al. Identification of genes involved in the four stages of colorectal cancer: Gene expression profiling. Mol. Cell. Probes 2018, 37, 39-47. [CrossRef] [PubMed]

99. Jiang, P.; Zhang, D. Maternal embryonic leucine zipper kinase (MELK): A novel regulator in cell cycle control, embryonic development, and cancer. Int. J. Mol. Sci. 2013, 14, 21551-21560. [CrossRef]

100. Liu, G.; Zhan, W.; Guo, W.; Hu, F.; Qin, J.; Li, R.; Liao, X. MELK Accelerates the Progression of Colorectal Cancer via Activating the FAK/Src Pathway. Biochem. Genet. 2020, 58, 771-782. [CrossRef]

101. Raemaekers, T.; Ribbeck, K.; Beaudouin, J.; Annaert, W.; Van Camp, M.; Stockmans, I.; Smets, N.; Bouillon, R.; Ellenberg, J.; Carmeliet, G. NuSAP, a novel microtubule-associated protein involved in mitotic spindle organization. J. Cell Biol. 2003, 162, 1017-1029. [CrossRef]

102. Lane, H.A.; Nigg, E.A. Antibody microinjection reveals an essential role for human polo-like kinase 1 (Plk1) in the functional maturation of mitotic centrosomes. J. Cell Biol. 1996, 135, 1701-1713. [CrossRef] 
103. Han, D.P.; Zhu, Q.L.; Cui, J.T.; Wang, P.X.; Qu, S.; Cao, Q.F.; Zong, Y.P.; Feng, B.; Zheng, M.H.; Lu, A.G. Polo-like kinase 1 is overexpressed in colorectal cancer and participates in the migration and invasion of colorectal cancer cells. Med. Sci. Monit. 2012. [CrossRef]

104. Kang, S.W.; Chae, H.Z.; Seo, M.S.; Kim, K.; Baines, I.C.; Rhee, S.G. Mammalian peroxiredoxin isoforms can reduce hydrogen peroxide generated in response to growth factors and tumor necrosis factor-alpha. J. Biol. Chem. 1998, 273, 6297-6302. [CrossRef]

105. Li, H.X.; Sun, X.Y.; Yang, S.M.; Wang, Q.; Wang, Z.Y. Peroxiredoxin 1 promoted tumor metastasis and angiogenesis in colorectal cancer. Pathol. Res. Pract. 2018. [CrossRef] [PubMed]

106. Chu, G.; Li, J.; Zhao, Y.; Liu, N.; Zhu, X.; Liu, Q.; Wei, D.; Gao, C. Identification and verification of PRDX1 as an inflammation marker for colorectal cancer progression. Am. J. Transl. Res. 2016, 8, 842-859. [PubMed]

107. Kang, D.H.; Lee, D.J.; Lee, S.; Lee, S.Y.; Jun, Y.; Kim, Y.; Kim, Y.; Lee, J.S.; Lee, D.K.; Lee, S.; et al. Interaction of tankyrase and peroxiredoxin II is indispensable for the survival of colorectal cancer cells. Nat. Commun. 2017, 8, 1-14. [CrossRef] [PubMed]

108. Thelander, L. Ribonucleotide reductase and mitochondrial DNA synthesis. Nat. Genet. 2007, 39, 703-704. [CrossRef]

109. Chabes, A.; Thelander, L. Controlled protein degradation regulates ribonucleotide reductase activity in proliferating mammalian cells during the normal cell cycle and in response to DNA damage and replication blocks. J. Biol. Chem. 2000, 275, 17747-17753. [CrossRef]

110. Reichard, P. From RNA to DNA, why so many ribonucleotide reductases? Science 1993, 260, 1773-1777. [CrossRef] [PubMed]

111. Fukai, T.; Ushio-Fukai, M. Superoxide dismutases: Role in redox signaling, vascular function, and diseases. Antioxid. Redox Signal. 2011, 15, 1583-1606. [CrossRef]

112. Warsinggih; Irawan, B.; Labeda, I.; Lusikooy, R.E.; Sampetoding, S.; Kusuma, M.I.; Uwuratuw, J.A.; Syarifuddin, E.; Prihantono; Faruk, M. Association of superoxide dismutase enzyme with staging and grade of differentiation colorectal cancer: A crosssectional study. Ann. Med. Surg. 2020, 58, 194-199. [CrossRef]

113. Szlachta, K.; Manukyan, A.; Raimer, H.M.; Singh, S.; Salamon, A.; Guo, W.; Lobachev, K.S.; Wang, Y.-H. Topoisomerase II contributes to DNA secondary structure-mediated double-stranded breaks. Nucleic Acids Res. 2020, 48, 6654-6671. [CrossRef]

114. Sønderstrup, I.M.H.; Nygård, S.B.; Poulsen, T.S.; Linnemann, D.; Stenvang, J.; Nielsen, H.J.; Bartek, J.; Brünner, N.; Nørgaard, P.; Riis, L. Topoisomerase-1 and -2A gene copy numbers are elevated in mismatch repair-proficient colorectal cancers. Mol. Oncol. 2015. [CrossRef] [PubMed]

115. Aubrey, B.J.; Strasser, A.; Kelly, G.L. Tumor-Suppressor Functions of the TP53 Pathway. Cold Spring Harb. Perspect. Med. 2016, 6, a026062. [CrossRef]

116. Nalkiran, I.; Turan, S.; Arikan, S.; Kahraman, Ö.T.; Acar, L.; Yaylim, I.; Ergen, A. Determination of gene expression and serum levels of MnSOD and GPX1 in colorectal cancer. Anticancer Res. 2015, 35, 255-260.

117. Romagnani, P.; Lasagni, L.; Annunziato, F.; Serio, M.; Romagnani, S. CXC chemokines: The regulatory link between inflammation and angiogenesis. Trends Immunol. 2004, 25, 201-209. [CrossRef]

118. Xu, H.; Ma, Y.; Zhang, J.; Gu, J.; Jing, X.; Lu, S.; Fu, S.; Huo, J. Identification and Verification of Core Genes in Colorectal Cancer. BioMed Res. Int. 2020. [CrossRef]

119. Guda, K.; Veigl, M.L.; Varadan, V.; Nosrati, A.; Ravi, L.; Lutterbaugh, J.; Beard, L.; Willson, J.K.V.; Sedwick, W.D.; Wang, Z.J.; et al. Novel recurrently mutated genes in African American colon cancers. Proc. Natl. Acad. Sci. USA 2015, 112, 1149-1154. [CrossRef] [PubMed]

120. Kim, S.J.; Nakayama, S.; Miyoshi, Y.; Taguchi, T.; Tamaki, Y.; Matsushima, T.; Torikoshi, Y.; Tanaka, S.; Yoshida, T.; Ishihara, H.; et al. Determination of the specific activity of CDK1 and CDK2 as a novel prognostic indicator for early breast cancer. Ann. Oncol. 2008. [CrossRef] [PubMed]

121. Piao, J.; Zhu, L.; Sun, J.; Li, N.; Dong, B.; Yang, Y.; Chen, L. High expression of CDK1 and BUB1 predicts poor prognosis of pancreatic ductal adenocarcinoma. Gene 2019. [CrossRef]

122. Chang, J.T.; Wang, H.M.; Chang, K.W.; Chen, W.H.; Wen, M.C.; Hsu, Y.M.; Yung, B.Y.M.; Chen, I.H.; Liao, C.T.; Hsieh, L.L.; et al Identification of differentially expressed genes in oral squamous cell carcinoma (OSCC): Overexpression of NPM, CDK1 and NDRG1 and underexpression of CHES1. Int. J. Cancer 2005. [CrossRef]

123. Wu, M.; Liu, Z.; Li, X.; Zhang, A.; Lin, D.; Li, N. Analysis of potential key genes in very early hepatocellular carcinoma. World J. Surg. Oncol. 2019. [CrossRef]

124. Xu, Y.; Zhang, X.; Hu, X.; Zhou, W.; Zhang, P.; Zhang, J.; Yang, S.; Liu, Y. The effects of lncRNA MALAT1 on proliferation, invasion and migration in colorectal cancer through regulating SOX9. Mol. Med. 2018, 24, 1-15. [CrossRef]

125. Mancilla, V.J.; Peeri, N.C.; Silzer, T.; Basha, R.; Felini, M.; Jones, H.P.; Phillips, N.; Tao, M.H.; Thyagarajan, S.; Vishwanatha, J.K. Understanding the Interplay Between Health Disparities and Epigenomics. Front. Genet. 2020, 11, 1-14. [CrossRef]

126. Kawakami, H.; Zaanan, A.; Sinicrope, F.A. Microsatellite instability testing and its role in the management of colorectal cancer. Curr. Treat. Options Oncol. 2015, 16, 30. [CrossRef] [PubMed]

127. Nojadeh, J.N.; Behrouz Sharif, S.; Sakhinia, E. Microsatellite instability in colorectal cancer. EXCLI J. 2018, 17, 159-168. [CrossRef]

128. Vodenkova, S.; Jiraskova, K.; Urbanova, M.; Kroupa, M.; Slyskova, J.; Schneiderova, M.; Levy, M.; Buchler, T.; Liska, V.; Vodickova, L.; et al. Base excision repair capacity as a determinant of prognosis and therapy response in colon cancer patients. DNA Repair (Amst) 2018, 72, 77-85. [CrossRef] [PubMed] 
129. Murphy, K.M.; Zhang, S.; Geiger, T.; Hafez, M.J.; Bacher, J.; Berg, K.D.; Eshleman, J.R. Comparison of the microsatellite instability analysis system and the Bethesda panel for the determination of microsatellite instability in colorectal cancers. J. Mol. Diagn. 2006, 8, 305-311. [CrossRef] [PubMed]

130. Suraweera, N.; Duval, A.; Reperant, M.; Vaury, C.; Furlan, D.; Leroy, K.; Seruca, R.; Iacopetta, B.; Hamelin, R. Evaluation of tumor microsatellite instability using five quasimonomorphic mononucleotide repeats and pentaplex PCR. Gastroenterology 2002, 123, 1804-1811. [CrossRef]

131. Ashktorab, H.; Smoot, D.T.; Carethers, J.M.; Rahmanian, M.; Kittles, R.; Vosganian, G.; Doura, M.; Nidhiry, E.; Naab, T.; Momen, B.; et al. High incidence of microsatellite instability in colorectal cancer from African Americans. Clin. Cancer Res. 2003, 9, 1112-1117.

132. Gonzalez-Pons, M.; Cruz-Correa, M. Colorectal Cancer Disparities in Latinos: Genes vs. Environment. In Advancing the Science of Cancer in Latinos; Ramirez, A.G., Trapido, E.J., Eds.; Springer International Publishing: Cham, Switzerland, 2020 ; pp. 35-41. ISBN 978-3-030-29286-7.

133. Ashktorab, H.; Ahuja, S.; Kannan, L.; Llor, X.; Nathan, E.; Xicola, R.M.; Laiyemo, A.O.; Carethers, J.M.; Brim, H.; Nouraie, M. A meta-analysis of MSI frequency and race in colorectal cancer. Oncotarget 2016, 7, 34546-34557. [CrossRef]

134. Ning, Y.; Manegold, P.C.; Hong, Y.K.; Zhang, W.; Pohl, A.; Lurje, G.; Winder, T.; Yang, D.; LaBonte, M.J.; Wilson, P.M.; et al. Interleukin-8 is associated with proliferation, migration, angiogenesis and chemosensitivity in vitro and in vivo in colon cancer cell line models. Int. J. Cancer 2011. [CrossRef]

135. Michael, M.Z.; O'Connor, S.M.; Van Holst Pellekaan, N.G.; Young, G.P.; James, R.J. Reduced Accumulation of Specific MicroRNAs in Colorectal Neoplasia. Mol. Cancer Res. 2003, 1, 882-891. [PubMed]

136. Schetter, A.J.; Okayama, H.; Harris, C.C. The role of MicroRNAs in colorectal cancer. Cancer J. 2012, 18, 244-252. [CrossRef] [PubMed]

137. Lu, Y.J.; Wang, P.; Peng, J.; Wang, X.; Zhu, Y.W.; Shen, N. Meta-analysis Reveals the Prognostic Value of Circulating Tumour Cells Detected in the Peripheral Blood in Patients with Non-Metastatic Colorectal Cancer. Sci. Rep. 2017, 7, 1-9. [CrossRef] [PubMed]

138. Bork, U.; Rahbari, N.N.; Schölch, S.; Reissfelder, C.; Kahlert, C.; Büchler, M.W.; Weitz, J.; Koch, M. Circulating tumour cells and outcome in non-metastatic colorectal cancer: A prospective study. Br. J. Cancer 2015, 112, 1306-1313. [CrossRef] [PubMed]

139. Grillet, F.; Bayet, E.; Villeronce, O.; Zappia, L.; Lagerqvist, E.L.; Lunke, S.; Charafe-Jauffret, E.; Pham, K.; Molck, C.; Rolland, N.; et al. Circulating tumour cells from patients with colorectal cancer have cancer stem cell hallmarks in ex vivo culture. Gut 2017, 66, 1802-1810. [CrossRef]

140. Xiao, Y.; Zhong, J.; Zhong, B.; Huang, J.; Jiang, L.; Jiang, Y.; Yuan, J.; Sun, J.; Dai, L.; Yang, C.; et al. Exosomes as potential sources of biomarkers in colorectal cancer. Cancer Lett. 2020, 476, 13-22. [CrossRef]

141. Bracci, L.; Lozupone, F.; Parolini, I. The role of exosomes in colorectal cancer disease progression and response to therapy. Cytokine Growth Factor Rev. 2020, 51, 84-91. [CrossRef]

142. He, X.; Zhong, X.; Hu, Z.; Zhao, S.; Wei, P.; Li, D. An insight into small extracellular vesicles: Their roles in colorectal cancer progression and potential clinical applications. Clin. Transl. Med. 2020, 10. [CrossRef]

143. Strubberg, A.M.; Madison, B.B. MicroRNAs in the etiology of colorectal cancer: Pathways and clinical implications. DMM Dis. Model. Mech. 2017, 10, 197-214. [CrossRef]

144. Cannell, I.G.; Kong, Y.W.; Bushell, M. How do microRNAs regulate gene expression? Biochem. Soc. Trans. 2008, 36, 1224-1231. [CrossRef]

145. Calin, G.A.; Dumitru, C.D.; Shimizu, M.; Bichi, R.; Zupo, S.; Noch, E.; Aldler, H.; Rattan, S.; Keating, M.; Rai, K.; et al. Frequent deletions and down-regulation of micro-RNA genes miR15 and miR16 at 13q14 in chronic lymphocytic leukemia. Proc. Natl. Acad. Sci. USA 2002. [CrossRef] [PubMed]

146. Slattery, M.L.; Herrick, J.S.; Pellatt, D.F.; Stevens, J.R.; Mullany, L.E.; Wolff, E.; Hoffman, M.D.; Samowitz, W.S.; Wolff, R.K. MicroRNA profiles in colorectal carcinomas, adenomas and normal colonic mucosa: Variations in miRNA expression and disease progression. Carcinogenesis 2015. [CrossRef] [PubMed]

147. Yin, Y.; Song, M.; Gu, B.; Qi, X.; Hu, Y.; Feng, Y.; Liu, H.; Zhou, L.; Bian, Z.; Zhang, J.; et al. Systematic analysis of key miRNAs and related signaling pathways in colorectal tumorigenesis. Gene 2016. [CrossRef] [PubMed]

148. Uratani, R.; Toiyama, Y.; Kitajima, T.; Kawamura, M.; Hiro, J.; Kobayashi, M.; Tanaka, K.; Inoue, Y.; Mohri, Y.; Mori, T.; et al. Diagnostic potential of cell-free and exosomal MicroRNAs in the identification of patients with high-risk colorectal adenomas. PLoS ONE 2016, 11, e0160722. [CrossRef]

149. Nagy, Z.B.; Wichmann, B.; Kalmár, A.; Galamb, O.; Barták, B.K.; Spisák, S.; Tulassay, Z.; Molnár, B. Colorectal adenoma and carcinoma specific miRNA profiles in biopsy and their expression in plasma specimens. Clin. Epigenetics 2017. [CrossRef] [PubMed]

150. Tadano, T.; Kakuta, Y.; Hamada, S.; Shimodaira, Y.; Kuroha, M.; Kawakami, Y.; Kimura, T.; Shiga, H.; Endo, K.; Masamune, A.; et al. MicroRNA-320 family is downregulated in colorectal adenoma and affects tumor proliferation by targeting CDK6. World J. Gastrointest. Oncol. 2016. [CrossRef]

151. Sun, D.; Yu, F.; Ma, Y.; Zhao, R.; Chen, X.; Zhu, J.; Zhang, C.Y.; Chen, J.; Zhang, J. MicroRNA-31 activates the RAS pathway and functions as an oncogenic MicroRNA in human colorectal cancer by repressing RAS p21 GTPase activating protein 1 (RASA1). J. Biol. Chem. 2013. [CrossRef] 
152. Le Rolle, A.F.; Chiu, T.K.; Zeng, Z.; Shia, J.; Weiser, M.R.; Paty, P.B.; Chiu, V.K. Oncogenic KRAS activates an embryonic stem cell-like program in human colon cancer initiation. Oncotarget 2016. [CrossRef]

153. Bartley, A.N.; Yao, H.; Barkoh, B.A.; Ivan, C.; Mishra, B.M.; Rashid, A.; Calin, G.A.; Luthra, R.; Hamilton, S.R. Complex patterns of altered microRNA expression during the adenoma-adenocarcinoma sequence for microsatellite-stable colorectal cancer. Clin. Cancer Res. 2011. [CrossRef]

154. Zhu, J.; Xu, Y.; Liu, S.; Qiao, L.; Sun, J.; Zhao, Q. MicroRNAs Associated With Colon Cancer: New Potential Prognostic Markers and Targets for Therapy. Front. Bioeng. Biotechnol. 2020. [CrossRef]

155. Li, E.; Ji, P.; Ouyang, N.; Zhang, Y.; Wang, X.Y.; Rubin, D.C.; Davidson, N.O.; Bergamaschi, R.; Shroyer, K.R.; Burke, S.; et al. Differential expression of miRNAs in colon cancer between African and Caucasian Americans: Implications for cancer racial health disparities. Int. J. Oncol. 2014, 45, 587-594. [CrossRef] [PubMed]

156. Shen, K.; Cao, Z.; Zhu, R.; You, L.; Zhang, T. The dual functional role of MicroRNA-18a (miR-18a) in cancer development. Clin. Transl. Med. 2019, 8, 32. [CrossRef]

157. Kumarswamy, R.; Volkmann, I.; Thum, T. Regulation and function of miRNA-21 in health and disease. RNA Biol. 2011, 8. [CrossRef] [PubMed]

158. Bautista-Sánchez, D.; Arriaga-Canon, C.; Pedroza-Torres, A.; De La Rosa-Velázquez, I.A.; González-Barrios, R.; ContrerasEspinosa, L.; Montiel-Manríquez, R.; Castro-Hernández, C.; Fragoso-Ontiveros, V.; Álvarez-Gómez, R.M.; et al. The Promising Role of miR-21 as a Cancer Biomarker and Its Importance in RNA-Based Therapeutics. Mol. Ther. Nucleic Acids 2020, 20, 409-420. [CrossRef] [PubMed]

159. Chang, P.Y.; Chen, C.C.; Chang, Y.S.; Tsai, W.S.; You, J.F.; Lin, G.P.; Chen, T.W.; Chen, J.S.; Chan, E.C. MicroRNA-223 and microRNA-92a in stool and plasma samples act as complementary biomarkers to increase colorectal cancer detection. Oncotarget 2016, 7, 10663-10675. [CrossRef] [PubMed]

160. Chen, H.; Xu, Z. Hypermethylation-Associated Silencing of miR-125a and miR-125b: A Potential Marker in Colorectal Cancer. Dis. Markers 2015, 2015. [CrossRef]

161. Bu, J.; Li, H.; Li, X.; Liu, L.; Sun, W.; Xiao, T. Prognostic Role of MicroRNA-126 for Survival in Malignant Tumors: A Systematic Review and Meta-Analysis. Dis. Markers 2015, 2015, 1-11. [CrossRef]

162. Li, X.M.; Wang, A.M.; Zhang, J.; Yi, H. Down-regulation of miR-126 expression in colorectal cancer and its clinical significance. Med. Oncol. 2011, 28, 1054-1057. [CrossRef]

163. Valeri, N.; Braconi, C.; Gasparini, P.; Murgia, C.; Lampis, A.; Paulus-Hock, V.; Hart, J.R.; Ueno, L.; Grivennikov, S.I.; Lovat, F.; et al. MicroRNA-135b promotes cancer progression by acting as a downstream effector of oncogenic pathways in colon cancer. Cancer Cell 2014, 25, 469-483. [CrossRef]

164. Akao, Y.; Nakagawa, Y.; Naoe, T. MicroRNA-143 and -145 in colon cancer. DNA Cell Biol. 2007, 26, 311-320. [CrossRef]

165. Catela Ivkovic, T.; Voss, G.; Cornella, H.; Ceder, Y. microRNAs as cancer therapeutics: A step closer to clinical application. Cancer Lett. 2017, 407, 113-122. [CrossRef] [PubMed]

166. Van Roosbroeck, K.; Fanini, F.; Setoyama, T.; Ivan, C.; Rodriguez-Aguayo, C.; Fuentes-Mattei, E.; Xiao, L.; Vannini, I.; Redis, R.S.; D'Abundo, L.; et al. Combining anti-miR-155 with chemotherapy for the treatment of lung cancers. Clin. Cancer Res. 2017, 23, 2891-2904. [CrossRef] [PubMed]

167. Zhang, X.F.; Tu, R.; Li, K.; Ye, P.; Cui, X. Tumor Suppressor PTPRJ Is a Target of miR-155 in Colorectal Cancer. J. Cell. Biochem. 2017, 118, 3391-3400. [CrossRef] [PubMed]

168. Wang, B.; Shen, Z.L.; Gao, Z.D.; Zhao, G.; Wang, C.Y.; Yang, Y.; Zhang, J.Z.; Yan, Y.C.; Shen, C.; Jiang, K.W.; et al. MiR-194, commonly repressed in colorectal cancer, suppresses tumor growth by regulating the MAP4K4/c- Jun/MDM2 signaling pathway. Cell Cycle 2015, 14, 1046-1058. [CrossRef] [PubMed]

169. Liu, X.; Zhang, Z.; Sun, L.; Chai, N.; Tang, S.; Jin, J.; Hu, H.; Nie, Y.; Wang, X.; Wu, K.; et al. microRNA-499-5p promotes cellular invasion and tumor metastasis in colorectal cancer by targeting FOXO4 and PDCD4. Carcinogenesis 2011, 32, 1798-1805. [CrossRef]

170. Liu, G.; Li, B. Role of miRNA in transformation from normal tissue to colorectal adenoma and cancer. J. Cancer Res. Ther. 2019, 15, 278-285. [CrossRef] [PubMed]

171. Hamzehzadeh, L.; Yousefi, M.; Ghaffari, S.H. Colorectal cancer screening: A comprehensive review to recent non-invasive methods. Int. J. Hematol. Stem Cell Res. 2017, 11, 251-262.

172. Issa, I.A.; NouredDine, M. Colorectal cancer screening: An updated review of the available options. World J. Gastroenterol. 2017, 23, 5086-5096. [CrossRef]

173. Link, A.; Balaguer, F.; Shen, Y.; Nagasaka, T.; Lozano, J.J.; Boland, C.R.; Goel, A. Fecal microRNAs as novel biomarkers for colon cancer screening. Cancer Epidemiol. Biomark. Prev. 2010. [CrossRef]

174. Ahmed, F.E.; Ahmed, N.C.; Vos, P.W.; Bonnerup, C.; Atkins, J.N.; Casey, M.; Nuovo, G.J.; Naziri, W.; Wiley, J.E.; Mota, H.; et al. Diagnostic MicroRNA markers to screen for sporadic human colon cancer in stool: I. Proof of principle. Cancer Genom. Proteom. 2013, 10, 93-113.

175. Carini, F.; Mazzola, M.; Rappa, F.; Jurjus, A.; Geagea, A.G.; Al Kattar, S.; Bou-Assi, T.; Jurjus, R.; Damiani, P.; Leone, A.; et al. Colorectal Carcinogenesis: Role of Oxidative Stress and Antioxidants. Anticancer Res. 2017, 37, 4759-4766.

176. Aceto, G.M.; Catalano, T.; Curia, M.C. Molecular Aspects of Colorectal Adenomas: The Interplay among Microenvironment, Oxidative Stress, and Predisposition. bioMed Res. Int. 2020, 2020, 1726309. [CrossRef] [PubMed] 
177. Lobo, V.; Patil, A.; Phatak, A.; Chandra, N. Free radicals, antioxidants and functional foods: Impact on human health. Pharmacogn. Rev. 2010, 4, 118-126. [CrossRef] [PubMed]

178. Bhattacharyya, A.; Chattopadhyay, R.; Mitra, S.; Crowe, S.E. Oxidative stress: An essential factor in the pathogenesis of gastrointestinal mucosal diseases. Physiol. Rev. 2014, 94, 329-354. [CrossRef] [PubMed]

179. Cordani, M.; Butera, G.; Pacchiana, R.; Masetto, F.; Mullappilly, N.; Riganti, C.; Donadelli, M. Mutant p53-Associated Molecular Mechanisms of ROS Regulation in Cancer Cells. Biomolecules 2020, 10, 361. [CrossRef]

180. Li, H.; Hong, Z.-H. Mitochondrial DNA mutations in human tumor cells (Review). Oncol. Lett. 2012, 4, 868-872. [CrossRef]

181. Ivanova, D.; Zhelev, Z.; Aoki, I.; Bakalova, R.; Higashi, T. Overproduction of reactive oxygen species - obligatory or not for induction of apoptosis by anticancer drugs. Chin. J. Cancer Res. 2016, 28, 383-396. [CrossRef]

182. Janion, K.; Szczepańska, E.; Nowakowska-Zajdel, E.; Strzelczyk, J.; Copija, A. Selected Oxidative Stress Markers in Colorectal Cancer Patients in Relation to Primary Tumor Location-A Preliminary Research. Medicina 2020, 56, 47. [CrossRef]

183. Liu, H.; Liu, X.; Zhang, C.; Zhu, H.; Xu, Q.; Bu, Y.; Lei, Y. Redox Imbalance in the Development of Colorectal Cancer. J. Cancer 2017, 8, 1586-1597. [CrossRef]

184. Pereira, C.; Grácio, D.; Teixeira, J.P.; Magro, F. Oxidative Stress and DNA Damage: Implications in Inflammatory Bowel Disease. Inflamm. Bowel Dis. 2015, 21, 2403-2417. [CrossRef]

185. Sengupta, T.; Torgersen, M.L.; Kassahun, H.; Vellai, T.; Simonsen, A.; Nilsen, H. Base excision repair AP endonucleases and mismatch repair act together to induce checkpoint-mediated autophagy. Nat. Commun. 2013, 4. [CrossRef]

186. Wyatt, M.D.; Wilson, D.M. Participation of DNA repair in the response to 5-fluorouracil. Cell. Mol. Life Sci. 2009, 66, 788-799. [CrossRef]

187. Basak, D.; Uddin, M.N.; Hancock, J. The role of oxidative stress and its counteractive utility in colorectal cancer (CRC). Cancers 2020, 12, 3336. [CrossRef] [PubMed]

188. Vodicka, P.; Stetina, R.; Polakova, V.; Tulupova, E.; Naccarati, A.; Vodickova, L.; Kumar, R.; Hanova, M.; Pardini, B.; Slyskova, J.; et al. Association of DNA repair polymorphisms with DNA repair functional outcomes in healthy human subjects. Carcinogenesis 2007, 28, 657-664. [CrossRef] [PubMed]

189. Martindale, J.L.; Holbrook, N.J. Cellular response to oxidative stress: Signaling for suicide and survival. J. Cell. Physiol. 2002, 192, 1-15. [CrossRef] [PubMed]

190. Fulda, S.; Gorman, A.M.; Hori, O.; Samali, A. Cellular Stress Responses: Cell Survival and Cell Death. Int. J. Cell Biol. 2010, 2010, 214074. [CrossRef]

191. Tavassolifar, M.J.; Vodjgani, M.; Salehi, Z.; Izad, M. The Influence of Reactive Oxygen Species in the Immune System and Pathogenesis of Multiple Sclerosis. Autoimmune Dis. 2020, 2020, 5793817. [CrossRef]

192. Kim, S.J.; Kim, H.S.; Seo, Y.R. Understanding of ROS-Inducing Strategy in Anticancer Therapy. Oxid. Med. Cell. Longev. 2019, 2019. [CrossRef]

193. Stone, W.L.; Krishnan, K.; Campbell, S.E.; Palau, V.E. The role of antioxidants and pro-oxidants in colon cancer. World J. Gastrointest. Oncol. 2014, 6, 55-66. [CrossRef]

194. Leufkens, A.M.; Van Duijnhoven, F.J.B.; Woudt, S.H.S.; Siersema, P.D.; Jenab, M.; Jansen, E.H.J.M.; Pischon, T.; Tjønneland, A.; Olsen, A.; Overvad, K.; et al. Biomarkers of oxidative stress and risk of developing colorectal cancer: A cohort-nested case-control study in the European Prospective Investigation into Cancer and Nutrition. Am. J. Epidemiol. 2012, 175, 653-663. [CrossRef]

195. Gackowski, D.; Banaszkiewicz, Z.; Rozalski, R.; Jawien, A.; Olinski, R. Persistent oxidative stress in colorectal carcinoma patients. Int. J. Cancer 2002, 101, 395-397. [CrossRef] [PubMed]

196. Breitzig, M.; Bhimineni, C.; Lockey, R.; Kolliputi, N. 4-Hydroxy-2-nonenal: A critical target in oxidative stress? Am. J. Physiol. Physiol. 2016, 311, C537-C543. [CrossRef]

197. Slyskova, J.; Lorenzo, Y.; Karlsen, A.; Carlsen, M.H.; Novosadova, V.; Blomhoff, R.; Vodicka, P.; Collins, A.R. Both genetic and dietary factors underlie individual differences in DNA damage levels and DNA repair capacity. DNA Repair (Amst) 2014, 16, 66-73. [CrossRef] [PubMed]

198. Marrocco, I.; Altieri, F.; Peluso, I. Measurement and Clinical Significance of Biomarkers of Oxidative Stress in Humans. Oxid. Med. Cell. Longev. 2017, 2017, 6501046. [CrossRef] [PubMed]

199. Broedbaek, K.; Siersma, V.; Henriksen, T.; Weimann, A.; Petersen, M.; Andersen, J.T.; Jimenez-Solem, E.; Hansen, L.J.; Henriksen, J.E.; Bonnema, S.J.; et al. Urinary markers of nucleic acid oxidation and cancer in type 2 diabetes. Redox Biol. 2015, 4, 34-39. [CrossRef] [PubMed]

200. Broedbaek, K.; Siersma, V.; Henriksen, T.; Weimann, A.; Petersen, M.; Andersen, J.T.; Jimenez-Solem, E.; Hansen, L.J.; Henriksen, J.E.; Bonnema, S.J.; et al. Association between urinary markers of Nucleic Acid Oxidation andMortality in Type 2 Diabetes A population-based cohort study. Diabetes Care 2013, 36, 669-676. [CrossRef]

201. Kant, M.; Akış, M.; Çalan, M.; Arkan, T.; Bayraktar, F.; Dizdaroglu, M.; İşlekel, H. Elevated urinary levels of 8-oxo-2'deoxyguanosine, ( $\left.5^{\prime} \mathrm{R}\right)$ - and $\left(5^{\prime} \mathrm{S}\right)-8,5^{\prime}$-cyclo-2'-deoxyadenosines, and 8-iso-prostaglandin $\mathrm{F} 2 \alpha$ as potential biomarkers of oxidative stress in patients with prediabetes. DNA Repair (Amst) 2016, 48, 1-7. [CrossRef]

202. Wu, L.L.; Chiou, C.C.; Chang, P.Y.; Wu, J.T. Urinary 8-OHdG: A marker of oxidative stress to DNA and a risk factor for cancer, atherosclerosis and diabetics. Clin. Chim. Acta 2004, 339, 1-9. [CrossRef] [PubMed]

203. Loft, S.; Svoboda, P.; Kasai, H.; Tjønneland, A.; Vogel, U.; Møller, P.; Overvad, K.; Raaschou-Nielsen, O. Prospective study of 8-oxo-7,8-dihydro-2'-deoxyguanosine excretion and the risk of lung cancer. Carcinogenesis 2006, 27, 1245-1250. [CrossRef] 
204. Sova, H.; Jukkola-Vuorinen, A.; Puistola, U.; Kauppila, S.; Karihtala, P. 8-Hydroxydeoxyguanosine: A new potential independent prognostic factor in breast cancer. Br. J. Cancer 2010, 102, 1018-1023. [CrossRef]

205. Zhang, L.; Yu, J. Role of Apoptosis in Colon Cancer Biology, Therapy, and Prevention. Curr. Colorectal Cancer Rep. 2013, 9, 331-340. [CrossRef] [PubMed]

206. Abraha, A.M.; Ketema, E.B. Apoptotic pathways as a therapeutic target for colorectal cancer treatment. World J. Gastrointest. Oncol. 2016, 8, 583-591. [CrossRef] [PubMed]

207. Ismail, N.I.; Othman, I.; Abas, F.; Lajis, N.H.; Naidu, R. Mechanism of Apoptosis Induced by Curcumin in Colorectal Cancer. Int. J. Mol. Sci. 2019, 20, 2454. [CrossRef] [PubMed]

208. Alcaide, J.; Funez, R.; Rueda, A.; Perez-Ruiz, E.; Pereda, T.; Rodrigo, I.; Coveñas, R.; Muñoz, M.; Redondo, M. The role and prognostic value of apoptosis in colorectal carcinoma. BMC Clin. Pathol. 2013, 13, 24. [CrossRef]

209. Pandurangan, A.K.; Divya, T.; Kumar, K.; Dineshbabu, V.; Velavan, B.; Sudhandiran, G. Colorectal carcinogenesis: Insights into the cell death and signal transduction pathways: A review. World J. Gastrointest. Oncol. 2018, 10, 244-259. [CrossRef]

210. Li, H.; Zhang, J.; Tong, J.H.; Chan, A.W.; Yu, J.; Kang, W.; To, K.F. Targeting the Oncogenic p53 Mutants in Colorectal Cancer and Other Solid Tumors. Int. J. Mol. Sci. 2019, 20, 5999. [CrossRef]

211. Li, X.-L.; Zhou, J.; Chen, Z.-R.; Chng, W.-J. P53 mutations in colorectal cancer - molecular pathogenesis and pharmacological reactivation. World J. Gastroenterol. 2015, 21, 84-93. [CrossRef]

212. Ramesh, P.; Medema, J.P. BCL-2 family deregulation in colorectal cancer: Potential for BH3 mimetics in therapy. Apoptosis 2020, 25, 305-320. [CrossRef]

213. Devetzi, M.; Kosmidou, V.; Vlassi, M.; Perysinakis, I.; Aggeli, C.; Choreftaki, T.; Zografos, G.N.; Pintzas, A. Death receptor 5 (DR5) and a 5-gene apoptotic biomarker panel with significant differential diagnostic potential in colorectal cancer. Sci. Rep. 2016, 6, 36532. [CrossRef]

214. Manne, U.; Jadhav, T.; Putcha, B.-D.K.; Samuel, T.; Soni, S.; Shanmugam, C.; Suswam, E.A. Molecular Biomarkers of Colorectal Cancer and Cancer Disparities: Current Status and Perspective. Curr. Colorectal Cancer Rep. 2016, 12, 332-344. [CrossRef] [PubMed]

215. Yoon, H.H.; Shi, Q.; Alberts, S.R.; Goldberg, R.M.; Thibodeau, S.N.; Sargent, D.J.; Sinicrope, F.A. Racial Differences in BRAF/KRAS Mutation Rates and Survival in Stage III Colon Cancer Patients. J. Natl. Cancer Inst. 2015, 107, 1-10. [CrossRef] [PubMed]

216. Qian, H.-R.; Shi, Z.-Q.; Zhu, H.-P.; Gu, L.-H.; Wang, X.-F.; Yang, Y. Interplay between apoptosis and autophagy in colorectal cancer. Oncotarget 2017, 8, 62759-62768. [CrossRef] [PubMed] 